\title{
An update on genome-wide association studies of hypertension
}

\author{
Jie Zheng ${ }^{1}$, Dabeeru C. Rao ${ }^{2}$ and Gang Shi ${ }^{3 *}$
}

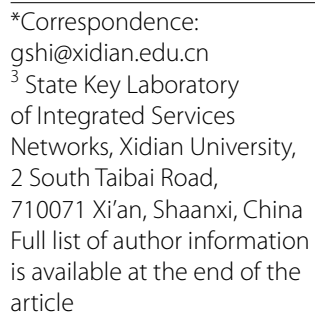

\begin{abstract}
Hypertension is a major global health problem associated with cardiovascular and cerebrovascular diseases. It is well established that blood pressure and hypertension are common complex phenotypes affected by multiple genetic and environmental factors. Contemporary genomic tools make it possible to genotype millions of genetic variants across the human genome in an efficient, reliable, and cost-effective manner, which has transformed hypertension genetics research. International collaborations/ consortia have enabled the use of unprecedentedly large sample sizes for gene discovery and replication. Genome-wide association studies have reported more than 60 loci associated with blood pressure or hypertension, most of which were not expected to have any association with these phenotypes. In contrast to linkage and candidate gene studies, the reproducibility of genome-wide association studies is much higher and some results have been verified across different ethnicities. These novel findings have provided potential targets for pharmacotherapy and clues for personalized prevention and treatment of hypertension. Although only a small proportion of blood pressure variation is attributed to the genetic variants identified so far, more variants are likely to be discovered by employing larger sample sizes, studying gene-environment interactions, or by exploring low-frequency or rare variants. Advances in epigenetics, which examines trait variation not caused by differences in DNA sequences, will probably reveal a new and important class of genetic components for hypertension.
\end{abstract}

Keywords: Blood pressure, Hypertension, Genetics, Genome-wide association study, Genes

\section{Background}

Hypertension affects approximately 50 million individuals in the United States and approximately 1 billion individuals worldwide (Chobanian et al. 2003), and it is estimated to account for $4.5 \%$ of the global burden of disease (Whitworth and World Health Organization International Society of Hypertension Writing Group 2003). Hypertension plays a major etiologic role in the development of cerebrovascular disease, cardiovascular disease (CVD), and renal failure (Whitworth and World Health Organization International Society of Hypertension Writing Group 2003). CVD alone is responsible for one-third of global deaths and is a leading and increasing contributor to the global burden of disease (World Health Organization 2002). For 40 to 70-year-old individuals, each increment of $20 \mathrm{mmHg}$ in systolic blood pressure (SBP) or $10 \mathrm{mmHg}$ in diastolic blood pressure (DBP) doubles the risk of CVD across the entire blood pressure (BP)

\section{望 Springer}

(c) 2015 Zheng et al. This article is distributed under the terms of the Creative Commons Attribution 4.0 International License (http:// creativecommons.org/licenses/by/4.0/), which permits unrestricted use, distribution, and reproduction in any medium, provided you give appropriate credit to the original author(s) and the source, provide a link to the Creative Commons license, and indicate if changes were made. 
range from $115 / 75$ to $185 / 115 \mathrm{mmHg}$ (Lewington et al. 2002). The risk of CVD can be lowered by controlling BP. In multiple clinical trials, antihypertensive therapy has been associated with significant reductions in stroke incidence (averaging 35-40\%), myocardial infarction (20-25\%), and heart failure (over $50 \%$ ) (Neal et al. 2000). Understanding the genetics of BP can advance our understanding of the physiology of BP regulation and the pathology of hypertension. Finding genes associated with BP could potentially uncover novel targets for pharmacotherapy. Furthermore, the development of precision medicine based on genetic profiles of individuals could increase the efficiency of prevention and treatment of hypertension (Collins and Varmus 2015).

For a long time, BP has been known to be a complex trait influenced by multiple genetic and environmental factors (Lifton 1996; Hamet et al. 1998). Its heritability ranges from 30 to $50 \%$, estimated in family and twin studies (Miall and Oldham 1963). Early success in dissecting the genetic architecture of hypertension revealed 12 genes that cause a monogenic type of hypertension. These genes are members of two pathways: renal sodium handling and steroid hormone metabolism, the latter of which includes mineralocorticoid receptor activity (Ehret and Caulfield 2013). Inheritance of monogenic hypertension in families follows a clear segregation pattern and casual variants are typically rare and of large effect sizes. However, due to low frequencies of these variants, there is still a lack of clear understanding of essential hypertension (Pickering 1965), which has no evident cause and accounts for $95 \%$ cases of hypertension (Carretero and Oparil 2000).

Genome-wide linkage analysis tests the association between the transmission of genomic regions and phenotypic similarity among family members (Thomas 2004); it was one of the most widely used methods for genetic studies of hypertension. A number of genome-wide linkage scans for BP or hypertension have provided some significant or suggestive linkage signals, whereas external replications have been very difficult (Binder 2007; Simino et al. 2012). Limited statistical power of linkage analysis, small sample sizes, and small effect sizes of underlying variants may be the main reasons. Alternatively, the candidate gene approach focuses on genes in several major pathways that are involved in BP homeostasis. As only a small number of polymorphisms were under investigation, the burden of multiple testing was alleviated, which allowed the identification of variants of small effects in moderate sample sizes. The major limitation is that this method relies on the existing biological knowledge of BP regulation, therefore precludes a large number of genes and chromosomal regions that may harbor novel associated variants lacking immediate physiological relationships with hypertension (Charchar et al. 2008). As in linkage analyses, replication of findings from candidate gene studies were challenging, such as in Basson et al. (2012). With advancements in genotyping technology, hundreds of thousands to millions of single-nucleotide polymorphisms (SNPs) could be measured on a single microarray at a reasonable cost (Fan et al. 2000). The study of hypertension genetics called for a paradigm shift to the genome-wide association studies (GWAS). In this paper, we summarize recent advances in genetic studies of BP/hypertension, focusing on study designs and strategies used therein. We also share our thoughts on some future directions. For a comprehensive review on the genetic and molecular aspects of hypertension, refer to Padmanabhan et al. (2015). 


\section{Review}

\section{Overview of GWAS methods}

GWAS utilize a dense panel of SNPs to investigate associations between genetic markers and complex traits, such as BP. SNPs are distributed across the entire human genome and are measured by high-throughput genotyping platforms, which are commercially available. Many GWAS further impute unmeasured common SNPs based on haplotype data provided by the International HapMap Project (International HapMap Consortium 2005, 2007) and computational approaches implemented in genetic software, such as MACH (Li and Abecasis 2006), IMPUTE (Marchini et al. 2007), and BIMBAM (Servin and Stephens 2007). The number of SNPs in GWAS varies from hundreds of thousands to millions. Association between each SNP and a phenotype of interest is tested typically by a linear or logistic regression for continuous or dichotomous phenotypes, respectively. Additive genetic models are widely assumed in the majority of GWAS. A stringent genome-wide significance threshold of $P<5 \times 10^{-8}$ is routinely used as a correction for multiple testing, which is based on the estimation of approximately 1 million independent SNPs in a population of European decent (Pe'er et al. 2008). To boost statistical power and find genetic variants with small effects, international collaborations have been established among studies and are organized in consortia. GWAS analyses are first conducted in participating studies; results are then combined using meta-analysis, which helps to achieve an overall sample size much larger than that based on any individual study. This approach has an inherent advantage, in which each study is able to analyze its own data using a standard analysis plan, but otherwise taking study-specific attributes into account, such as adjusting for study-specific covariates that are not common across all participating studies. More recently, GWAS are imputing millions of common and rare variants based on the 1000 Genomes Project (1000 Genomes Project Consortium 2012). Appropriate methods and analysis strategies for effectively harvesting such huge data sets are still evolving.

\section{GWAS of quantitative BP phenotypes in diverse populations}

GWAS of quantitative BP phenotypes have been conducted in diverse populations including samples of European ancestry, African ancestry and East Asians. The first GWAS (Wellcome Trust Case Control Consortium 2007) adopted a case-control study design using 3000 shared controls and 14,000 cases (2000 for hypertension) of European ancestry to study seven complex diseases simultaneously. About 500,000 genotyped SNPs were tested yielding 24 association signals at $P<5 \times 10^{-7}$ significance level for six diseases. Hypertension was the only disease without any significant results and none of the variants previously associated with hypertension showed evidence of association. The first GWAS of quantitative BP phenotypes, SBP and DBP, was conducted by the Framingham Heart Study (Levy et al. 2007). The study analyzed approximately 71,000 genome-wide SNPs, including 1400 family subjects. No significant results were found either. These two studies highlighted the complexity of the genetic mechanisms underlying BP regulation. Research then progressed to population-based cohort studies. Recognizing the need for much larger sample sizes, collaborative consortia were established to look for genes associated with $\mathrm{BP} /$ hypertension. 
The first two successful GWAS of BP were reported by the Cohorts for Heart and Aging Research in Genomic Epidemiology (CHARGE) consortium (Levy et al. 2009) and the Global Blood Pressure Genetics (Global BPgen) consortium (Newton-Cheh et al. 2009). The CHARGE consortium consisted of six population-based cohort studies with a sample size of 29,000. Global BPgen included 17 cohorts ascertained through population-based sampling or case-control studies with a sample size of 34,000 at the discovery phase. Eight genomic loci were identified to be associated with SBP or DBP by each study; three loci overlapped in both groups. Both consortia analyzed crosssectional SBP and DBP phenotypes, which are commonly measured in many clinical or epidemiology studies. The additive genetic main effect was tested by both consortia, ignoring possible dominant, recessive, or interaction effects. Approximately 2.5 million SNPs were imputed and tested providing a common ground for the meta-analysis of the results from studies using various platforms for genotyping. Most of the 13 unique loci identified were novel except for CYP17A1-NT5C2 and MTHFR-NPPB that contain BP regulation genes previously known. Results from these two studies and others are listed in Table 1.

A follow-up expanded investigation was conducted by the International Consortium of Blood Pressure (ICBP) (ICBP 2011), consisting of 29 studies of European ancestry, many of which were from CHARGE and Global BPgen consortia. ICBP included GWAS data on 69,000 individuals for gene discovery and 133,000 for replication. The study replicated the previous 13 loci effectively and discovered 16 new loci significant at the genome-wide level. Another study by the ICBP consortium (Wain et al. 2011) analyzed two derived BP phenotypes: mean arterial pressure (MAP) and pulse pressure (PP). MAP, computed as the sum of two-thirds of DBP and one-third of SBP, represents an average $\mathrm{BP}$ in a cardiac cycle; PP, a measure of stiffness of main arteries, is the difference between SBP and DBP. This study discovered four novel PP loci and two novel MAP loci. The signals for MAP were strongly associated with both SBP and DBP, reflecting a high correlation between these three BP traits.

BP loci were also discovered in GWAS with much smaller sample size, for example CDH13 (Org et al. 2009; $N=1600$ ) and STK39 (Wang et al. 2009; $N=7000$ ). However, although these studies did not show genome-wide significance during the discovery phase or lacked immediate replication, results were replicated later by other independent studies, suggesting that the so-called "winner's curse" (Yu et al. 2007) for replication could be a "complexity's blessing" at the discovery phase (Shi et al. 2011).

The largest GWAS effort to date involving participants of African origin was done by the Continental Origins and Genetic Epidemiology Network (COGENT) (Franceschini et al. 2013). Discovery samples were obtained from 19 studies with an aggregate sample size of 29,000 individuals. Due to the lack of sufficient samples from similar genetic backgrounds, replication was conducted using a trans-ethnic design with 10,000 samples of African ancestry, 69,000 of European ancestry, and 20,000 of East Asian ancestry. For the top discovery signals $\left(P<1 \times 10^{-5}\right)$, meta-analysis was conducted by combining all replication samples from the three ethnicities. Five loci reached genome-wide significance level, three of which were not previously reported to be associated with BP. Other GWAS on samples of African ancestry conducted earlier by Adeyemo et al. (2009) and Fox et al. (2011) also reported genome-wide significant associations. Due to limited 
Table 1 Blood pressure/hypertension loci reported by genome-wide association studies and candidate gene studies

\begin{tabular}{|c|c|c|c|c|c|}
\hline Chr & Genes & Lead SNP & Position & Trait & Ethnicity \\
\hline $1 \mathrm{p} 36.22$ & CASZ1 & rs880315 & $10,736,809$ & SBP & $\begin{array}{l}\text { EA( Levy et al. 2009) } \\
\text { Asian (Takeuchi et al. 2010) } \\
\text { EA (Ho et al. 2011) } \\
\text { Asian (Kato et al. 2011) } \\
\text { Asian (Lu et al. 2014) } \\
\text { EA (Simino et al. 2014) } \\
\text { EA (Ganesh et al. 2014) } \\
\text { EA (Tragante et al. 2014) }\end{array}$ \\
\hline $1 p 36.22$ & MTHFR-NPPB & rs17367504 & $11,802,721$ & SBP & $\begin{array}{l}\text { EA (Newton-Cheh et al. 2009) } \\
\text { EA (Tomaszewski et al. 2010) } \\
\text { Asian (Takeuchi et al. 2010) } \\
\text { EA (Johnson et al. 2011 b) } \\
\text { EA (Ho et al. 2011) } \\
\text { Asian (Kato et al. 2011) } \\
\text { EA (ICBP 2011) } \\
\text { EA (Ganesh et al. 2013) } \\
\text { EA (Simino et al. 2014) } \\
\text { EA (Ganesh et al. 2014) } \\
\text { EA (Tragante et al. 2014) }\end{array}$ \\
\hline $1 p 13.2$ & ST7L-MOV10 & rs2932538 & $112,673,921$ & $\begin{array}{l}\text { SBP } \\
\text { DBP }\end{array}$ & $\begin{array}{l}\text { EA (ICBP 2011) } \\
\text { Asian (Kato et al. 2011) } \\
\text { Asian (Lu et al. 2014) } \\
\text { EA (Tragante et al. 2014) }\end{array}$ \\
\hline $1 \mathrm{q} 32.1$ & MDM4 & rs2169137 & $204,528,785$ & $\mathrm{DBP}$ & $\begin{array}{l}\text { EA (Ganesh et al. 2013) } \\
\text { EA (Tragante et al. 2014) }\end{array}$ \\
\hline $1 q 42.2$ & $A G T$ & rs2004776 & $230,712,956$ & $\mathrm{HT}$ & $\begin{array}{l}\text { EA (Johnson et al. 2011 b) } \\
\text { EA (Johnson et al. 2011a) } \\
\text { EA (Ganesh et al. 2014) } \\
\text { EA (Tragante et al. 2014) }\end{array}$ \\
\hline $2 p 23.2$ & KCNK3 & rs1275988 & $26,691,496$ & $\begin{array}{l}\text { SBP } \\
\text { MAP }\end{array}$ & EA (Ganesh et al. 2014) \\
\hline $2 q 11.2$ & FER1L5 & rs7599598 & $96,686,103$ & $\mathrm{DBP}$ & EA (Ganesh et al. 2014) \\
\hline $2 q 24.3$ & FIGN & rs13002573 & $164,058,698$ & $\begin{array}{l}\text { PP } \\
\text { MAP }\end{array}$ & $\begin{array}{l}\text { EA (Wain et al. 2011) } \\
\text { Asian (Kato et al. 2011) } \\
\text { Asian (Hong et al. 2012) } \\
\text { Asian (Lu et al. 2014) } \\
\text { EA (Simino et al. 2014) } \\
\text { EA (Ganesh et al. 2014) } \\
\text { EA (Tragante et al. 2014) }\end{array}$ \\
\hline $2 q 24.3$ & STK39 & rs6749447 & $168,184,876$ & SBP & $\begin{array}{l}\text { EA (Wang et al. 2009) } \\
\text { AA (Adeyemo et al. 2009) } \\
\text { EA (Tragante et al. 2014) }\end{array}$ \\
\hline $2 q 32.1$ & PDEIA & rs16823124 & $182,359,400$ & $\begin{array}{l}\text { DBP } \\
\text { MAP }\end{array}$ & EA (Tragante et al. 2014) \\
\hline $2 \mathrm{q} 32.2$ & PMS1 & rs5743185 & $189,873,112$ & SBP & $\begin{array}{l}\text { AA (Adeyemo et al. 2009) } \\
\text { EA (Levy et al. 2009) }\end{array}$ \\
\hline $3 p 25.3$ & $\mathrm{HRHI}$ & rs347591 & $11,248,436$ & SBP & $\begin{array}{l}\text { EA (Ganesh et al. 2013) } \\
\text { EA (Tragante et al. 2014) }\end{array}$ \\
\hline $3 p 24.1$ & SLC4A7 & rs13082711 & $27,496,418$ & $\mathrm{DBP}$ & $\begin{array}{l}\text { EA (ICBP 2011) } \\
\text { Asian (Lu et al. 2014) } \\
\text { EA (Tragante et al. 2014) }\end{array}$ \\
\hline $3 p 22.1$ & ULK4 & rs9815354 & $41,871,159$ & DBP & $\begin{array}{l}\text { EA (Levy et al. 2009) } \\
\text { EA (ICBP 2011) } \\
\text { EA + AA + Asian (Franceschini et al. 2013) } \\
\text { Asian (Lu et al. 2014) } \\
\text { EA (Ganesh et al. 2014) } \\
\text { EA (Tragante et al. 2014) }\end{array}$ \\
\hline
\end{tabular}


Table 1 continued

\begin{tabular}{|c|c|c|c|c|c|}
\hline Chr & Genes & Lead SNP & Position & Trait & Ethnicity \\
\hline $3 p 21.31$ & MAP4 & rs319690 & $47,885,994$ & MAP & $\begin{array}{l}\text { EA (Wain et al. 2011) } \\
\text { Asian (Hong et al. 2012) } \\
\text { Asian (Kelly et al. 2013) } \\
\text { EA (Simino et al. 2014) } \\
\text { EA (Tragante et al. 2014) }\end{array}$ \\
\hline $3 p 21.1$ & CACNA1D & rs9810888 & $53,601,568$ & DBP & Asian (Lu et al. 2014) \\
\hline $3 q 26.1$ & MIR1263 & rs16833934 & $164,019,462$ & DBP & EA (Simino et al. 2014) \\
\hline $3 q 26.2$ & MECOM & rs419076 & $169,383,098$ & $\begin{array}{l}\text { SBP } \\
\text { DBP }\end{array}$ & $\begin{array}{l}\text { EA (ICBP 2011) } \\
\text { EA (Tragante et al. 2014) }\end{array}$ \\
\hline $4 q 12$ & CHIC2 & rs871606 & $53,933,078$ & PP & $\begin{array}{l}\text { EA (Wain et al. 2011) } \\
\text { Asian (Hong et al. 2012) } \\
\text { EA (Tragante et al. 2014) }\end{array}$ \\
\hline $4 q 21.21$ & FGF5 & rs16998073 & $80,263,187$ & DBP & $\begin{array}{l}\text { EA (Newton-Cheh et al. 2009) } \\
\text { Asian (Takeuchi et al. 2010) } \\
\text { Asian (Tabara et al. 2010) } \\
\text { Asian (Kato et al. 2011) } \\
\text { EA (ICBP 2011) } \\
\text { Asian (Kelly et al. 2013) } \\
\text { Asian (Lu et al. 2014) } \\
\text { EA (Simino et al. 2014) } \\
\text { EA (Tragante et al. 2014) }\end{array}$ \\
\hline $4 q 24$ & SLC39A8 & rs13107325 & $102,267,552$ & $\begin{array}{l}\text { SBP } \\
\text { DBP }\end{array}$ & $\begin{array}{l}\text { EA (ICBP 2011) } \\
\text { EA (Tragante et al. 2014) }\end{array}$ \\
\hline $4 q 25$ & ENPEP & rs6825911 & $110,460,482$ & $\mathrm{DBP}$ & $\begin{array}{l}\text { Asian (Kato et al. 2011) } \\
\text { EA (Tragante et al. 2014) }\end{array}$ \\
\hline $4 q 32.1$ & GUCY1A3-GUCY1B3 & rs13139571 & $155,724,361$ & $\mathrm{DBP}$ & $\begin{array}{l}\text { EA (ICBP 2011) } \\
\text { Asian (Lu et al. 2014) } \\
\text { EA (Tragante et al. 2014) }\end{array}$ \\
\hline $5 p 13.3$ & NPR3-C5orf23 & rs1173771 & $32,814,922$ & $\begin{array}{l}\text { SBP } \\
\text { DBP } \\
\text { HT }\end{array}$ & $\begin{array}{l}\text { EA (ICBP 2011) } \\
\text { AA (Zhu et al. 2011) } \\
\text { EA (Johnson et al. 2011 b) } \\
\text { Asian (Kato et al. 2011) } \\
\text { EA (Ganesh et al. 2014) } \\
\text { EA (Tragante et al. 2014) }\end{array}$ \\
\hline $5 q 33.3$ & $E B F 1$ & rs11953630 & $158,418,394$ & $\begin{array}{l}\text { SBP } \\
\text { DBP }\end{array}$ & $\begin{array}{l}\text { EA (ICBP 2011) } \\
\text { EA (Simino et al. 2014) } \\
\text { EA (Tragante et al. 2014) }\end{array}$ \\
\hline $6 p 22.2$ & HFE & rs1799945 & $26,090,951$ & $\begin{array}{l}\text { SBP } \\
\text { DBP } \\
\text { HT }\end{array}$ & $\begin{array}{l}\text { EA (ICBP 2011) } \\
\text { EA (Johnson et al. 2011 b) } \\
\text { EA (Ganesh et al. 2013) } \\
\text { Asian (Lu et al. 2014) } \\
\text { EA (Simino et al. 2014) } \\
\text { EA (Ganesh et al. 2014) } \\
\text { EA (Tragante et al. 2014) }\end{array}$ \\
\hline $6 p 21.33$ & BAT2-CYP21A2 & rs805303 & $31,648,589$ & $\begin{array}{l}\text { SBP } \\
\text { DBP } \\
\text { HT }\end{array}$ & $\begin{array}{l}\text { EA (ICBP 2011) } \\
\text { Asian (Lu et al. 2014) } \\
\text { EA (Tragante et al. 2014) }\end{array}$ \\
\hline $6 p 21.32$ & HLA-DQB1 & rs2854275 & $32,660,651$ & $\mathrm{DBP}$ & EA (Tragante et al. 2014) \\
\hline $6 p 21.1$ & CRIP3 & rs10948071 & $43,312,975$ & PP & EA (Ganesh et al. 2014) \\
\hline $6 q 22.33$ & RSPO3 & rs13209747 & $126,794,309$ & $\begin{array}{l}\text { SBP } \\
\text { DBP }\end{array}$ & $\mathrm{EA}+\mathrm{AA}+$ Asian (Franceschini et al. 2013) \\
\hline $6 q 25.1$ & PLEKHG1 & rs17080102 & $150,683,634$ & $\begin{array}{l}\text { SBP } \\
\text { DBP }\end{array}$ & $\mathrm{EA}+\mathrm{AA}+$ Asian (Franceschini et al. 2013) \\
\hline $7 p 15.2$ & EVX1-HOXA & rs17428471 & $27,298,248$ & $\begin{array}{l}\text { SBP } \\
\text { DBP }\end{array}$ & $\mathrm{EA}+\mathrm{AA}+$ Asian (Franceschini et al. 2013) \\
\hline $7 p 12.3$ & IGFBP3 & rs2949837 & $45,954,779$ & PP & EA (Ganesh et al. 2014) \\
\hline $7 q 21.2$ & CDK6 & rs2282978 & $92,635,096$ & PP & EA (Tragante et al. 2014) \\
\hline
\end{tabular}


Table 1 continued

\begin{tabular}{|c|c|c|c|c|c|}
\hline Chr & Genes & Lead SNP & Position & Trait & Ethnicity \\
\hline $7 q 22.3$ & PIK3CG & rs17477177 & $106,771,412$ & PP & $\begin{array}{l}\text { EA (Wain et al. 2011) } \\
\text { EA (Simino et al. 2014) } \\
\text { EA (Ganesh et al. 2014) } \\
\text { EA (Tragante et al. 2014) }\end{array}$ \\
\hline $7 q 36.1$ & NOS3 & rs3918226 & $150,993,088$ & DBP & $\begin{array}{l}\text { EA (Johnson et al. 2011b) } \\
\text { EA (Salvi et al. 2012) } \\
\text { EA (Tragante et al. 2014) }\end{array}$ \\
\hline 8p23.1 & BLK-GATA4 & rs4841569 & $11,594,668$ & $\begin{array}{l}\text { SBP } \\
\text { MAP }\end{array}$ & $\begin{array}{l}\text { EA (Simino et al. 2014) } \\
\text { EA (Tragante et al. 2014) }\end{array}$ \\
\hline $8 \mathrm{q} 24.12$ & NOV & rs2071518 & $119,423,572$ & PP & $\begin{array}{l}\text { EA (Wain et al. 2011) } \\
\text { EA (Tragante et al. 2014) }\end{array}$ \\
\hline 10p12.31 & CACNB2 & rs11014166 & $18,419,869$ & DBP & $\begin{array}{l}\text { EA (Levy et al. 2009) } \\
\text { EA (Ho et al. 2011) } \\
\text { EA (ICBP 2011) } \\
\text { Asian (Lin et al. 2011) } \\
\text { EA (Simino et al. 2014) } \\
\text { EA (Ganesh et al. 2014) } \\
\text { EA (Tragante et al. 2014) }\end{array}$ \\
\hline $10 q 21.2$ & c10orf107 & rs1530440 & $61,764,833$ & DBP & $\begin{array}{l}\text { EA (Newton-Cheh et al. 2009) } \\
\text { EA (Ho et al. 2011) } \\
\text { Asian (Kato et al. 2011) } \\
\text { EA (ICBP 2011) } \\
\text { EA (Simino et al. 2014) } \\
\text { EA (Ganesh et al. 2014) } \\
\text { EA (Tragante et al. 2014) }\end{array}$ \\
\hline $10 q 22.2$ & $V C L$ & rs4746172 & $74,096,084$ & $\begin{array}{l}\text { DBP } \\
\text { MAP }\end{array}$ & EA (Tragante et al. 2014) \\
\hline 10q23.33 & PLCE1 & rs932764 & $94,136,183$ & $\begin{array}{l}\text { SBP } \\
\text { HT }\end{array}$ & $\begin{array}{l}\text { EA (ICBP 2011) } \\
\text { EA (Tragante et al. 2014) }\end{array}$ \\
\hline $10 q 24.32$ & CYP17A1-NT5C2 & rs1004467 & $102,834,750$ & SBP & $\begin{array}{l}\text { EA (Levy et al. 2009) } \\
\text { EA (Newton-Cheh et al. 2009) } \\
\text { Asian (Takeuchi et al. 2010) } \\
\text { Asian (Hong et al. 2010) } \\
\text { Asian (Tabara et al. 2010) } \\
\text { EA (Ho et al. 2011) } \\
\text { Asian (Kato et al. 2011) } \\
\text { EA (ICBP 2011) } \\
\text { Asian (Lin et al. 2011) } \\
\text { Asian (Kelly et al. 2013) } \\
\text { EA (Ganesh et al. 2013) } \\
\text { Asian (Lu et al. 2014) } \\
\text { Asian (Qi et al. 2014) } \\
\text { EA (Simino et al. 2014) } \\
\text { EA (Tragante et al. 2014) }\end{array}$ \\
\hline $10 q 25.3$ & $A D R B 1$ & rs2782980 & $114,021,768$ & MAP & $\begin{array}{l}\text { EA (Wain et al. 2011) } \\
\text { EA (Ganesh et al. 2013) } \\
\text { EA (Simino et al. 2014) } \\
\text { EA (Tragante et al. 2014) }\end{array}$ \\
\hline $11 \mathrm{p} 15.5$ & LSP1 & rs661348 & $1,884,062$ & MAP & $\begin{array}{l}\text { EA (Johnson et al. 2011 b) } \\
\text { EA (Ganesh et al. 2013) } \\
\text { EA (Tragante et al. 2014) }\end{array}$ \\
\hline $11 \mathrm{p} 15.4$ & $A D M$ & rs7129220 & $10,328,991$ & SBP & $\begin{array}{l}\text { EA (ICBP 2011) } \\
\text { EA (Tragante et al. 2014) }\end{array}$ \\
\hline
\end{tabular}


Table 1 continued

\begin{tabular}{|c|c|c|c|c|c|}
\hline Chr & Genes & Lead SNP & Position & Trait & Ethnicity \\
\hline $11 \mathrm{p} 15.1$ & PLEKHA7 & rs381815 & $16,880,721$ & SBP & $\begin{array}{l}\text { EA (Levy et al. 2009) } \\
\text { Asian (Hong et al. 2010) } \\
\text { EA (Ho et al. 2011) } \\
\text { EA (ICBP 2011) } \\
\text { EA (Johnson et al. 2011 b) } \\
\text { Asian (Lin et al. 2011) } \\
\text { EA + AA + Asian (Franceschini et al. 2013) } \\
\text { EA (Ganesh et al. 2013) } \\
\text { Asian (Lu et al. 2014) } \\
\text { EA (Simino et al. 2014) } \\
\text { EA (Tragante et al. 2014) }\end{array}$ \\
\hline $11 q 13.1$ & EHBPILI & rs4601790 & $65,586,435$ & $\begin{array}{l}\text { MAP } \\
\text { DBP }\end{array}$ & $\begin{array}{l}\text { EA (Simino et al. 2014) } \\
\text { EA (Tragante et al. 2014) }\end{array}$ \\
\hline $11 q 22.1$ & FLJ32810-TMEM133 & rs633185 & $100,722,807$ & $\begin{array}{l}\text { SBP } \\
\text { DBP } \\
\text { HT }\end{array}$ & $\begin{array}{l}\text { EA (ICBP 2011) } \\
\text { EA (Tragante et al. 2014) }\end{array}$ \\
\hline $11 q 24.3$ & ADAMTS8 & rs11222084 & $130,403,335$ & $\mathrm{PP}$ & $\begin{array}{l}\text { EA (Wain et al. 2011) } \\
\text { EA (Tragante et al. 2014) }\end{array}$ \\
\hline $12 q 13.13$ & HOXC4 & rs7297416 & $54,049,306$ & SBP & EA (Tragante et al. 2014) \\
\hline $12 q 21.33$ & $A T P 2 B 1$ & rs2681492 & $89,619,312$ & $\begin{array}{l}\text { SBP } \\
\text { DBP } \\
\text { HT }\end{array}$ & $\begin{array}{l}\text { EA (Levy et al. 2009) } \\
\text { Asian (Cho et al. 2009) } \\
\text { Asian (Takeuchi et al. 2010) } \\
\text { Asian (Hong et al. 2010) } \\
\text { Asian (Tabara et al. 2010) } \\
\text { EA (Johnson et al. 2011 b) } \\
\text { EA (Ho et al. 2011) } \\
\text { Asian (Kato et al. 2011) } \\
\text { EA (ICBP 2011) } \\
\text { Asian (Wang et al. 2013b) } \\
\text { Asian (Kelly et al. 2013) } \\
\text { EA (Ganesh et al. 2013) } \\
\text { Asian (Lu et al. 2014) } \\
\text { Asian (Qi et al. 2014) } \\
\text { EA (Simino et al. 2014) } \\
\text { EA (Ganesh et al. 2014) } \\
\text { EA (Tragante et al. 2014) }\end{array}$ \\
\hline $12 q 24.12$ & $\mathrm{SH} 2 \mathrm{~B} 3$ & rs3184504 & $111,446,804$ & $\begin{array}{l}\text { SBP } \\
\text { DBP }\end{array}$ & $\begin{array}{l}\text { EA (Levy et al. 2009) } \\
\text { EA (Newton-Cheh et al. 2009) } \\
\text { EA (Ho et al. 2011) } \\
\text { Asian (Kato et al. 2011) } \\
\text { EA (ICBP 2011) } \\
\text { AA (Fox et al. 2011) } \\
\text { EA (Ganesh et al. 2013) } \\
\text { Asian (Lu et al. 2014) } \\
\text { EA (Simino et al. 2014) } \\
\text { EA (Ganesh et al. 2014) } \\
\text { EA (Tragante et al. 2014) }\end{array}$ \\
\hline $12 q 24.13$ & $\mathrm{ALDH} 2$ & rs11066280 & $112,379,979$ & $\begin{array}{l}\text { SBP } \\
\text { DBP }\end{array}$ & $\begin{array}{l}\text { Asian (Kato et al. 2011) } \\
\text { Asian (Lu et al. 2014) } \\
\text { EA (Tragante et al. 2014) }\end{array}$ \\
\hline $12 q 24.21$ & TBX3-TBX5 & rs2384550 & $114,914,926$ & DBP & $\begin{array}{l}\text { EA (Levy et al. 2009) } \\
\text { Asian (Kato et al. 2011) } \\
\text { EA (ICBP 2011) } \\
\text { AA (Fox et al. 2011) } \\
\text { Asian (Lu et al. 2014) } \\
\text { Asian (Qi et al. 2014) } \\
\text { EA (Ganesh et al. 2014) } \\
\text { EA (Tragante et al. 2014) }\end{array}$ \\
\hline $12 q 24.21$ & MED13L & rs1 1067763 & $115,760,536$ & $\begin{array}{l}\text { SBP } \\
\text { DBP }\end{array}$ & Asian (Lu et al. 2014) \\
\hline $15 q 21.1$ & FBN1 & rs1036477 & $48,622,729$ & PP & EA (Tragante et al. 2014) \\
\hline
\end{tabular}


Table 1 continued

\begin{tabular}{|c|c|c|c|c|c|}
\hline Chr & Genes & Lead SNP & Position & Trait & Ethnicity \\
\hline $15 q 24.1$ & CYPIA1-ULK3 & rs6495122 & $74,833,304$ & DBP & $\begin{array}{l}\text { EA (Levy et al. 2009) } \\
\text { EA (Newton-Cheh et al. 2009) } \\
\text { Asian (Takeuchi et al. 2010) } \\
\text { Asian (Hong et al. 2010) } \\
\text { Asian (Tabara et al. 2010) } \\
\text { EA (Ho et al. 2011) } \\
\text { Asian (Kato et al. 2011) } \\
\text { EA (ICBP 2011) } \\
\text { AA (Fox et al. 2011) } \\
\text { EA (Ganesh et al. 2013) } \\
\text { EA (Simino et al. 2014) } \\
\text { EA (Ganesh et al. 2014) } \\
\text { EA (Tragante et al. 2014) }\end{array}$ \\
\hline $15 q 26.1$ & FURIN-FES & rs 2521501 & $90,894,158$ & $\begin{array}{l}\text { SBP } \\
\text { DBP }\end{array}$ & $\begin{array}{l}\text { EA (ICBP 2011) } \\
\text { EA (Ganesh et al. 2013) } \\
\text { EA (Tragante et al. 2014) }\end{array}$ \\
\hline $16 p 12.3$ & UMOD & rs13333226 & $20,354,332$ & $\mathrm{HT}$ & $\begin{array}{l}\text { EA (Padmanabhan et al. 2010) } \\
\text { EA (Tragante et al. 2014) }\end{array}$ \\
\hline $16 q 22.1$ & NFAT5 & rs33063 & $69,606,314$ & PP & EA (Tragante et al. 2014) \\
\hline $16 q 23.3$ & $\mathrm{CDH} 13$ & rs11646213 & $82,609,046$ & $\mathrm{HT}$ & $\begin{array}{l}\text { EA (Org et al. 2009) } \\
\text { AA (Adeyemo et al. 2009) } \\
\text { EA (Tragante et al. 2014) }\end{array}$ \\
\hline $17 q 21.32$ & GOSR2 & rs17608766 & $46,935,905$ & SBP & $\begin{array}{l}\text { EA (ICBP 2011) } \\
\text { EA (Simino et al. 2014) } \\
\text { EA (Tragante et al. 2014) }\end{array}$ \\
\hline $17 q 21.33$ & ZNF652 & rs16948048 & $49,363,104$ & DBP & $\begin{array}{l}\text { EA (Newton-Cheh et al. 2009) } \\
\text { EA (Ho et al. 2011) } \\
\text { Asian (Kato et al. 2011) } \\
\text { EA (ICBP 2011) } \\
\text { EA (Tragante et al. 2014) }\end{array}$ \\
\hline $20 p 12.2$ & $J A G 1$ & rs1327235 & $10,988,382$ & $\begin{array}{l}\text { SBP } \\
\text { DBP }\end{array}$ & $\begin{array}{l}\text { EA (ICBP 2011) } \\
\text { Asian (Lu et al. 2014) } \\
\text { EA (Tragante et al. 2014) }\end{array}$ \\
\hline $20 q 13.32$ & GNAS-EDN3 & rs6015450 & $59,176,062$ & $\begin{array}{l}\text { SBP } \\
\text { DBP } \\
\text { HT }\end{array}$ & $\begin{array}{l}\text { EA (ICBP 2011) } \\
\text { EA (Simino et al. 2014) } \\
\text { EA (Ganesh et al. 2014) } \\
\text { EA (Tragante et al. 2014) }\end{array}$ \\
\hline
\end{tabular}

Lead SNP and trait are as reported in the first reference for each locus listed in the table. Position is based on dbSNP 142/ hg38

Chr Chromosomal region, AA African Ancestry, EA European Ancestry, HT Hypertension

replication resources, neither of these replication efforts were successful except that the $P M S 1$ gene demonstrated suggestive evidence of association with SBP $\left(P=7.2 \times 10^{-7}\right)$ (Adeyemo et al. 2009; Levy et al. 2009).

African American is a recently admixed population, which is estimated to have an 80 \% African lineage and a 20 \% European lineage on average (Parra et al. 1998). Given significant differences in the prevalence of hypertension in populations of European and African ancestries (Rosamond et al. 2007), admixture mapping (Zhu et al. 2008) was conducted by the Candidate gene Association Resource (CARe) consortium (Zhu et al. 2011). The discovery sample included approximately 6000 unrelated African American subjects from five participating cohorts. Quantitative admixture analyses for SBP and DBP were carried out using 3200 ancestry informative SNPs. After correcting for multiple testing, three loci were significantly associated with SBP and one with DBP. In the meta-analysis of the replication set, which included six independent cohorts with a 
sample size of 11,000, a novel variant located between the SUB1 and NPR3 genes was identified and shown to be associated with SBP and DBP.

The first large meta-analysis of GWAS of BP traits among East Asians was conducted by the Asian Genetic Epidemiology Network (AGEN) consortium (Kato et al. 2011). AGEN-BP work group included 30,000 individuals from population and family-based studies as part of its two-stage discovery phase and 20,000 at the replication stage. The study identified six novel loci that were genome-wide significantly associated with SBP or DBP, and seven loci previously reported in populations of European decent. In a further study of MAP and PP by AGEN (Kelly et al. 2013), no novel loci were discovered when the five previously identified MAP loci and two PP loci were replicated (Wain et al. 2011). A recent meta-analysis of GWAS in a Chinese population was carried out with approximately 12,000 samples for discovery and 69,000 for replication (Lu et al. 2014). This work lead to the discovery of a total of three novel BP loci and replicated 14 previously reported loci.

\section{GWAS of dichotomous hypertension phenotypes}

Most GWAS findings discovered to date were based on quantitative BP traits, for which statistical power is generally larger than for dichotomous outcomes, such as hypertension status. Two studies have reported positive hypertension susceptibility loci. In one GWAS, authors used an extreme case-control design with 1600 hypertensive cases and 1700 controls for discovery, and 20,000 cases and 17,000 controls for replication (Padmanabhan et al. 2010). Compared to the usual case-control studies, cases and controls were drawn from the extremes of the BP distribution, which provided a much sharper contrast between the two groups. The top SNP near gene $U M O D$ was reported to be genomewide significant $\left(P=3.6 \times 10^{-11}\right)$. The SNP showed only suggestive association with SBP $\left(P=2.6 \times 10^{-5}\right)$ and DBP $\left(P=1.5 \times 10^{-5}\right)$ in population-based cohorts $(N=79,000)$, therefore would not be discovered by large GWAS of BP phenotypes. In another GWAS of hypertension, a classical two-stage case-control study showed genome-wide significance of an SNP $\left(P=2.6 \times 10^{-13}\right)$ in the promoter region of NOS3 (Salvi et al. 2012).

\section{Candidate gene studies of BP}

A number of candidate gene studies have been carried out focusing on genes associated with cardiovascular phenotypes. Methodologies for candidate gene studies have changed significantly in the GWAS era, making it possible to carry out meta-analyses with much larger samples and many more candidate genes in a single investigation using the genotype data from either a subset of GWAS data or measured using high-throughput genotyping microarrays. As a result, reproducibility of candidate gene studies has much improved. Using the Illumina HumanCVD BeadChip array (Keating et al. 2008), 50,000 SNPs capturing variants of approximately 2000 candidate genes for cardiovascular phenotypes in 25,000 individuals were genotyped (Johnson et al. 2011a). The study identified eight significant loci, of which LSP1 and NOS3 were novel, concurrently with Salvi et al. (2012). In a different study, 62,000 individuals of European ancestry were genotyped by the same array. This study discovered one novel SNP associated with SBP and one with DBP, and confirmed 10 previously known loci associated with SBP, DBP, MAP or PP. All results were confirmed in an additional 66,000 individuals (Ganesh et al. 2013). 
In a study with a larger sample size, 88,000 for discovery and 68,000 for replication, 11 novel BP loci were reported and 27 known associations were replicated (Tragante et al. 2014). As most known hypertension target genes were not significant in GWAS, associations of SBP and DBP with 30 genes known to be antihypertensive drug targets were examined. All GWAS SNPs within $60 \mathrm{~kb}$ of each target gene were analyzed. ADRB1 and $A G T$ reached genome-wide significance in this meta-analysis (Johnson et al. 2011b).

\section{GWAS of BP with gene-environment interactions}

Essential hypertension is known to be influenced by multiple susceptibility genes, environmental and lifestyle factors, as well as their interactions (Kunes and Zicha 2009). Inspired by the discoveries from analyzing the genetic main effect, researchers started looking for evidence of gene-environment interactions. A large-scale GWAS assessing the pervasiveness of gene-age interactions was recently carried out by CHARGE, Global BPgen, and ICBP consortia (Simino et al. 2014), which included approximately 56,000 individuals for discovery and 43,000 for replication. Samples were stratified by age, and the conventional genetic main effect was examined separately in age bins in each cohort. Meta-regression was then used to test genetic main effects together with interaction effects (Xu et al. 2013), which was more powerful than either of the marginal tests (Kraft et al. 2007). Two out of the 20 genome-wide significant loci were novel. Nine loci demonstrated nominal evidence $(P<0.05)$ of age-dependent effects on BP when testing the interactions alone, and five would have been missed by main-effect-only analysis. Those loci demonstrating age-dependent effects are of particular relevance to essential hypertension, which is marked by a chronically elevated BP.

Gene-alcohol interactions were evaluated in a relatively small sample of 6900 individuals from the Framingham Heart Study (Simino et al. 2013). Using the same test (2 degrees of freedom), a significant locus was discovered. The same group, based on the same sample, identified two significant loci by gene-education interaction analysis (Basson et al. 2014b), and seven loci by gene-smoking interaction analysis (Sung et al. 2014). As these results were not replicated in external samples, they were subject to further validations.

\section{GWAS of other BP phenotypes}

Despite the wide availability of cross-sectional BP phenotypes, which allows for the employment of large sample sizes, a single BP measurement is subject to random variations. A number of studies were conducted on other BP-related phenotypes, which are believed to have much larger signal-to-noise ratios. One investigation studied long-term averaging of quantitative BP traits, aimed at reducing the intra-individual variability due to the measurement error (Ganesh et al. 2014). Nineteen significant loci were identified by this study; additionally, four were uniquely identified by the analysis using a discovery sample of 47,000 and replication of 39,000. In contrast to the long-term average, a different study looked into visit-to-visit BP variability in 3800 and 15,000 individuals for discovery and replication, respectively. One locus showed genome-wide significance; however, the result has not been replicated (Yadav et al. 2013). A family study that included 2000 individuals from 500 European nuclear families showed association 
between a mean 24-h DBP and an SNP in the promoter regions of MTHFR and CLCN6 genes (Tomaszewski et al. 2010).

GWAS of BP responses to low-sodium, high-sodium, potassium interventions, and cold pressor test were reported (He et al. 2013). This study was based on a relatively small sample of 1900 Han Chinese subjects from approximately 700 families, of which 8 novel loci were discovered. Unlike in GWAS of clinical BP measurements, genetic variants associated with BP responses in such well-controlled experiments demonstrated much greater effect sizes. Estimated effect sizes varied from 0.5 to $6.9 \mathrm{mmHg}$ per coded allele. Due to the shortage of independent samples with the same intervention design, results could not be effectively replicated.

\section{Pharmacogenomic studies of BP}

Understanding the genetic basis of how hypertensive patients respond to antihypertensive medicines differently is crucial for the implementation of precision medicine. There are a few GWAS of hypertension using SNP-medication (antihypertensive medications) interactions in a pharmacogenomics setting. A genetic mechanism of BP responses to antihypertensive medicines was investigated by employing an extreme case-control design with approximately 200 individuals of African ancestry and 200 of European ancestry. Approximately 100,000 genome-wide SNPs were genotyped using the Affymetrix Gene Chip Human Mapping 100 K Array. One significant locus was reported to be associated with the DBP response to hydrochlorothiazide (Turner et al. 2008). In a further effort using 1,100,000 SNPs and 650 samples for discovery and 620 for replication (Turner et al. 2013), three loci showed genome-wide significance while not replicated. Combining all samples, one locus became genome-wide significant, which also showed a large effect of $4.2 \mathrm{mmHg}$ per coded allele. In another study, about 300 hypertensive patients were recruited for GWAS of BP responses to three antihypertensive medicines. Associations were tested between quantitative BP responses and approximately 300,000 SNPs, and no significant loci were detected (Kamide et al. 2013). Although SNPs underlying BP responses may have large effects, small sample sizes employed in current pharmacogenomic studies may have limited their discovery.

\section{Future directions}

There is no doubt that GWAS achieved considerable success in dissecting the genetic architecture of BP regulation with over 60 novel loci identified. However, a substantial proportion of heritability has not been accounted for. Known loci appear to explain less than $2.5 \%$ of the phenotypic variance for SBP and DBP (ICBP 2011). Rare variants, structural variations, gene-gene, and gene-environment interactions, among many others, have been suggested as potential sources for finding the missing heritability (Manolio et al. 2009).

For height, a classic complex trait with an estimated heritability of $80 \%, 697$ genomewide significant variants have been reported that together explain one-fifth of its heritability using samples of 253,000 individuals (Wood et al. 2014). For BP phenotypes, it was estimated that there are 116 (95\% confidence interval 57-174) independent BP variants, with the effect sizes similar to those reported previously (ICBP 2011), which are yet to be 
discovered. Meta-analyses based on much larger sample sizes may find more common variants which explain additional BP variation.

With the advent of next-generation sequencing technology (Metzker 2010), it is possible now to detect rare variants via deep sequencing of whole exomes or even the entire genome at a much lower cost. Rare functional mutations were found to have much larger effects on BP than common mutations (Ji et al. 2008), potentially explaining at least a portion of the missing heritability. Sequencing studies of BP/hypertension are still at the initial stages. Early experiments suggest that large sample sizes are necessary (Nguyen et al. 2013; Morrison et al. 2014). While large sample sizes may be able to identify novel rare variants, efficient and cost-effective experimental design can enhance the power of even moderate sample sizes for studying rare variants (Shi and Rao 2011). The recently announced "Initiative on Precision Medicine" by the United States government aims to assemble over time a longitudinal cohort of 1 million or more American subjects (Collins and Varmus 2015), which is likely to be a valuable resource for finding rare variants underlying BP regulation and many other human diseases.

Progress in testing gene-environment interactions has demonstrated great promise for discovering novel BP variants as summarized in this review. Gene-environment interaction studies very much complement current GWAS efforts, which focus solely on testing additive genetic main effect, and will likely help to explain a portion of non-additive heritability. The Gene-Lifestyle Interactions Working Group of CHARGE is leading a large international effort to evaluate gene-lifestyle interactions in large multi-ethnic populations with approximately 300,000 subjects for discovery and replication (Rao and Borecki, Coordinators). This great effort funded by the National Heart, Lung, and Blood Institute of the United States government (Rao and Borecki, Principal Investigators) will likely help decide whether interaction studies can help identify some of the missing heritability.

Genome-wide gene-gene interaction tests are more challenging given the much larger burden of multiple testing. In the first genome-wide SNP-SNP interaction study of highdensity lipoprotein cholesterol levels (van Leeuwen et al. 2014), no significant interaction was detected after Bonferroni correction of $P$ values. In a focused study of SNP-SNP interaction among a small set of inflammation genes, no interaction was found to be associated with BP at an experiment-wide significance level (Basson et al. 2014a).

Epigenetics investigates trait and gene expression variations that are not caused by changes in the DNA sequence; it includes DNA methylation, histone modification, and alteration of microRNA expression, and more (Cowley et al. 2012). There is evidence indicating that cardiovascular biomarkers are associated with epigenetic modifications (Baccarelli et al. 2010). Introduction of high-throughput technologies now enables epigenetic features to be comprehensively and quantitatively profiled across the genome. As most BP variants detected by GWAS reside in non-coding regions, suggesting regulatory roles, the study of epigenetics could potentially explain some of the BP variance mediated by the changes in gene expressions. Wang et al. (2011) has reviewed the potential of epigenetics in hypertension genetics. The first genome-wide methylation analysis was conducted in young African American males (Wang et al. 2013a). A CpG site in the SULF1 gene showed higher methylation levels in leukocytes of hypertension case 
subjects than in those of healthy controls, confirmed in subjects younger than 30 years. This illustrates the promising future of epigenetic study in essential hypertension.

\title{
Conclusions
}

GWAS of BP allowed the testing of millions of common variants across the human genome for the first time. Tens of BP loci have been identified and reproduced in large cohorts; however, many BP variations are yet to be accounted for. Employing larger sample sizes and studying individuals with diverse genetic backgrounds help to identify more common variants. Next-generation sequencing technology permits the investigation of rare variants, which potentially have much larger effects. Gene-environment interaction analyses may help to identify additional BP variation beyond the additive genetic main effect. With emerging epigenetic approaches, additional BP variance is likely to be explained by epigenetic differences in populations. It is hoped that advances in hypertension genetics will provide insights into the pathogenesis of hypertension, identify novel drug targets, and lead to the development of novel antihypertensive medicines as well as personalized prevention and treatments.

\begin{abstract}
Abbreviations
AGEN: Asian Genetic Epidemiology Network; BP: blood pressure; CARe: Candidate-gene Association Resource; CHARGE: Cohorts for Heart and Aging Research in Genomic Epidemiology; COGENT: Continental Origins and Genetic Epidemiology Network; CVD: cardiovascular disease; DBP: diastolic blood pressure; Global BPgen: global blood pressure genetics; GWAS: genome-wide association studies; ICBP: International Consortium of Blood Pressure; MAP: mean arterial pressure; PP: pulse pressure; SBP: systolic blood pressure; SNP: single-nucleotide polymorphism.
\end{abstract}

\section{Authors' contributions}

JZ conceived of the review and drafted the manuscript. DCR conceived of the review and revised the manuscript. GS conceived of the review, drafted the manuscript, and participated in its design and coordination. All authors read and approved the final manuscript.

\section{Author details}

${ }^{1}$ Clinical Research Center, The First Affiliated Hospital of Xi'an Jiaotong University, 227 West Yanta Road, 710061 Xi'an, Shaanxi, China. ${ }^{2}$ Division of Biostatistics, Washington University School of Medicine, 660 South Euclid Avenue, Campus Box 8067, Saint Louis, MO 63110, USA. ${ }^{3}$ State Key Laboratory of Integrated Services Networks, Xidian University, 2 South Taibai Road, 710071 Xi'an, Shaanxi, China.

\section{Acknowledgements}

This work was supported by Xidian University under Grant 7214616803.

\section{Competing interests}

The authors declare that they have no competing interests.

Received: 11 June 2015 Accepted: 5 October 2015

Published online: 14 October 2015

\section{References}

Adeyemo A, Gerry N, Chen G, Herbert A, Doumatey A, Huang H, Zhou J, Lashley K, Chen Y, Christman M, Rotimi C (2009) A genome-wide association study of hypertension and blood pressure in African Americans. PLoS Genet 5(7):e1000564. doi:10.1371/journal.pgen.1000564

Baccarelli A, Rienstra M, Benjamin EJ (2010) Cardiovascular epigenetics: basic concepts and results from animal and human studies. Circ Cardiovasc Genet 3(6):567-573. doi:10.1161/CIRCGENETICS.110.958744

Basson J, Simino J, Rao DC (2012) Between candidate genes and whole genomes: time for alternative approaches in blood pressure genetics. Curr Hypertens Rep 14(1):46-61. doi:10.1007/s11906-011-0241-8

Basson JJ, de las Fuentes L, Rao DC (2014a) Single nucleotide polymorphism-single nucleotide polymorphism interactions among inflammation genes in the genetic architecture of blood pressure in the Framingham Heart Study. Am J Hypertens 28(2):248-255. doi:10.1093/ajh/hpu132

Basson J, Sung YJ, Schwander K, Kume R, Simino J, de las Fuentes L, Rao DC (2014b) Gene-education interactions identify novel blood pressure loci in the Framingham Heart Study. Am J Hypertens 27(3):431-444. doi:10.1093/ajh/hpt283

Binder A (2007) A review of the genetics of essential hypertension. Curr Opin Cardiol 22(3):176-184. doi:10.1097/ HCO.0b013e3280d357f9 
Carretero OA, Oparil S (2000) Essential hypertension. Part I: definition and etiology. Circulation 101(3):329-335. doi:10.1161/01.CIR.101.3.329

Charchar F, Zimmerli L, Tomaszewski M (2008) The pressure of finding human hypertension genes: new tools, old dilemmas. J Hum Hypertens 22(12):821-828. doi:10.1038/jhh.2008.67

Cho YS, Go MJ, Kim YJ, Heo JY, Oh JH, Ban HJ, Yoon D, Lee MH, Kim DJ, Park M, Cha SH, Kim JW, Han BG, Min H, Ahn Y, Park MS, Han HR, Jang HY, Cho EY, Lee JE, Cho NH, Shin C, Park T, Park JW, Lee JK, Cardon L, Clarke G, McCarthy MI, Lee JY, Lee JK, Oh B, Kim HL (2009) A large-scale genome-wide association study of Asian populations uncovers genetic factors influencing eight quantitative traits. Nat Genet 41(5), pp. 527-34, doi: 10.1038/ng.357

Chobanian AV, Bakris GL, Black HR, Cushman WC, Green LA, Izzo JL, Jones DW, Materson BJ, Oparil S, Wright JT, Roccella EJ, the National High Blood Pressure Education Program Coordinating Committee (2003) The seventh report of the joint national committee on prevention, detection, evaluation, and treatment of high blood pressure: The JNC 7 report. JAMA 289(19):2560-2571. doi:10.1001/jama.289.19.2560

Collins FS, Varmus H (2015) A new initiative on precision medicine. N Engl J Med 372(9):793-795. doi:10.1056/ NEJMp1500523

Cowley AW Jr, Nadeau JH, Baccarelli A, Berecek K, Fornage M, Gibbons GH, Harrison DG, Liang M, Nathanielsz PW, O'Connor DT, Ordovas J, Peng W, Soares MB, Szyf M, Tolunay HE, Wood KC, Zhao K, Galis ZS (2012) Report of the National Heart, Lung, and Blood Institute Working Group on epigenetics and hypertension. Hypertension 59(5):899905. doi:10.1161/HYPERTENSIONAHA.111.190116

Ehret GB, Caulfield MJ (2013) Genes for blood pressure: an opportunity to understand hypertension. Eur Heart J 34(13):951-961. doi:10.1093/eurheartj/ehs455

Fan JB, Chen X, Halushka MK, Berno A, Huang X, Ryder T, Lipshutz RJ, Lockhart DJ, Chakravarti A (2000) Parallel genotyping of human SNPs using generic high-density oligonucleotide tag arrays. Genome Res 10(6):853-860. doi:10.1101/ gr.10.6.853

Fox ER, Young JH, Li Y, Dreisbach AW, Keating BJ, Musani SK, Liu K, Morrison AC, Ganesh S, Kutlar A, Ramachandran VS, Polak JF, Fabsitz RR, Dries DL, Farlow DN, Redline S, Adeyemo A, Hirschorn JN, Sun YV, Wyatt SB, Penman AD, Palmas W, Rotter JI, Townsend RR, Doumatey AP, Tayo BO, Mosley TH Jr, Lyon HN, Kang SJ, Rotimi CN, Cooper RS, Franceschini N, Curb JD, Martin LW, Eaton CB, Kardia SL, Taylor HA, Caulfield MJ, Ehret GB, Johnson T; International Consortium for Blood Pressure Genome-wide Association Studies (ICBP-GWAS), Chakravarti A, Zhu X, Levy D (2011) Association of genetic variation with systolic and diastolic blood pressure among African Americans: the Candidate Gene Association Resource study. Hum Mol Genet 20(11):2273-2284. doi:10.1093/hmg/ddr092

Franceschini N, Fox E, Zhang Z, Edwards TL, Nalls MA, Sung YJ, Tayo BO, Sun YV, Gottesman O, Adeyemo A, Johnson AD, Young JH, Rice K, Duan Q, Chen F, Li Y, Tang H, Fornage M, Keene KL, Andrews JS, Smith JA, Faul JD, Guangfa Z, Guo W, Liu Y, Murray SS, Musani SK, Srinivasan S, Velez Edwards DR, Wang H, Becker LC, Bovet P, Bochud M, Broeckel U, Burnier M, Carty C, Chasman DI, Ehret G, Chen WM, Chen G, Chen W, Ding J, Dreisbach AW, Evans MK, Guo X, Garcia ME, Jensen R, Keller MF, Lettre G, Lotay V, Martin LW, Moore JH, Morrison AC, Mosley TH, Ogunniyi A, Palmas W, Papanicolaou G, Penman A, Polak JF, Ridker PM, Salako B, Singleton AB, Shriner D, Taylor KD, Vasan R, Wiggins K, Williams SM, Yanek LR, Zhao W, Zonderman AB, Becker DM, Berenson G, Boerwinkle E, Bottinger E, Cushman M, Eaton C, Nyberg F, Heiss G, Hirschhron JN, Howard VJ, Karczewsk KJ, Lanktree MB, Liu K, Liu Y, Loos R, Margolis K, Snyder M; Asian Genetic Epidemiology Network Consortium, Psaty BM, Schork NJ, Weir DR, Rotimi CN, Sale MM, Harris T, Kardia SL, Hunt SC, Arnett D, Redline S, Cooper RS, Risch NJ, Rao DC, Rotter Jl, Chakravarti A, Reiner AP, Levy D, Keating BJ, Zhu X (2013) Genome-wide association analysis of blood-pressure traits in African-ancestry individuals reveals common associated genes in African and non-African populations. Am J Hum Genet 93(3):545-554. doi:10.1016/j. ajhg.2013.07.010

Ganesh SK, Tragante V, Guo W, Guo Y, Lanktree MB, Smith EN, Johnson T, Castillo BA, Barnard J, Baumert J, Chang YP, Elbers CC, Farrall M, Fischer ME, Franceschini N, Gaunt TR, Gho JM, Gieger C, Gong Y, Isaacs A, Kleber ME, Mateo Leach I, McDonough CW, Meijs MF, Mellander O, Molony CM, Nolte IM, Padmanabhan S, Price TS, Rajagopalan R, Shaffer J, Shah S, Shen H, Soranzo N, van der Most PJ, Van Iperen EP, Van Setten J, Vonk JM, Zhang L, Beitelshees AL, Berenson GS, Bhatt DL, Boer JM, Boerwinkle E, Burkley B, Burt A, Chakravarti A, Chen W, Cooper-Dehoff RM, Curtis SP, Dreisbach A, Duggan D, Ehret GB, Fabsitz RR, Fornage M, Fox E, Furlong CE, Gansevoort RT, Hofker MH, Hovingh GK, Kirkland SA, Kottke-Marchant K, Kutlar A, Lacroix AZ, Langaee TY, Li YR, Lin H, Liu K, Maiwald S, Malik R; CARDIOGRAM, METASTROKE, Murugesan G, Newton-Cheh C, O'Connell JR, Onland-Moret NC, Ouwehand WH, Palmas W, Penninx BW, Pepine CJ, Pettinger M, Polak JF, Ramachandran VS, Ranchalis J, Redline S, Ridker PM, Rose LM, Scharnag H, Schork NJ, Shimbo D, Shuldiner AR, Srinivasan SR, Stolk RP, Taylor HA, Thorand B, Trip MD, van Duijn CM, Verschuren WM, Wijmenga C, Winkelmann BR, Wyatt S, Young JH, Boehm BO, Caulfield MJ, Chasman DI, Davidson KW, Doevendans PA, Fitzgerald GA, Gums JG, Hakonarson H, Hillege HL, Illig T, Jarvik GP, Johnson JA, Kastelein JJ, Koenig W; LifeLines Cohort Study, März W, Mitchell BD, Murray SS, Oldehinkel AJ, Rader DJ, Reilly MP, Reiner AP, Schadt EE, Silverstein RL, Snieder $H$, Stanton AV, Uitterlinden AG, van der Harst $P$, van der Schouw $Y T$, Samani NJ, Johnson AD, Munroe PB, de Bakker PI, Zhu X, Levy D, Keating BJ, Asselbergs FW (2013) Loci influencing blood pressure identified using a cardiovascular gene-centric array. Hum Mol Genet 22(8):1663-1678. doi:10.1093/hmg/dds555

Ganesh SK, Chasman DI, Larson MG, Guo X, Verwoert G, Bis JC, Gu X, Smith AV, Yang ML, Zhang Y, Ehret G, Rose LM, Hwang SJ, Papanicolau GJ, Sijbrands EJ, Rice K, Eiriksdottir G, Pihur V, Ridker PM, Vasan RS, Newton-Cheh C; Global Blood Pressure Genetics Consortium, Raffel LJ, Amin N, Rotter J, Liu K, Launer LJ, Xu M, Caulfield M, Morrison AC, Johnson AD, Vaidya D, Dehghan A, Li G, Bouchard C, Harris TB, Zhang H, Boerwinkle E, Siscovick DS, Gao W, Uitterlinden AG, Rivadeneira F, Hofman A, Willer CJ, Franco OH, Huo Y, Witteman JC, Munroe PB, Gudnason V, Palmas W, van Duijn C, Fornage M, Levy D, Psaty BM, Chakravarti A (2014) Effects of long-term averaging of quantitative blood pressure traits on the detection of genetic associations. Am J Hum Genet 95(1):49-65. doi:10.1016/j. ajhg.2014.06.002

Genomes Project Consortium (2012) An integrated map of genetic variation from 1092 human genomes. Nature 491(7422):56-65. doi:10.1038/nature11632

Hamet P, Pausova Z, Adarichev V, Adaricheva K, Tremblay J (1998) Hypertension: genes and environment. J Hypertens 16(4):397-418 
He J, Kelly TN, Zhao Q, Li H, Huang J, Wang L, Jaquish CE, Sung YJ, Shimmin LC, Lu F, Mu J, Hu D, Ji X, Shen C, Guo D, Ma J, Wang R, Shen J, Li S, Chen J, Mei H, Chen CS, Chen S, Chen J, Li J, Cao J, Lu X, Wu X, Rice TK, Gu CC, Schwander K, Hamm LL, Liu D, Rao DC, Hixson JE, Gu D (2013) Genome-wide association study identifies 8 novel loci associated with blood pressure responses to interventions in Han Chinese. Circ Cardiovasc Genet 6(6):598-607. doi:10.1161/ CIRCGENETICS.113.000307

Ho JE, Levy D, Rose L, Johnson AD, Ridker PM, Chasman DI (2011) Discovery and replication of novel blood pressure genetic loci in the Women's Genome Health Study. J Hypertens 29(1):62-69. doi:10.1097/HJH.0b013e3283406927

Hong KW, Jin HS, Lim JE, Kim S, Go MJ, Oh B (2010) Recapitulation of two genomewide association studies on blood pressure and essential hypertension in the Korean population. J Hum Genet 55(6):336-341. doi:10.1038/jhg.2010.31

Hong KW, Min H, Heo BM, Joo SE, Kim SS, Kim Y (2012) Recapitulation of genome-wide association studies on pulse pressure and mean arterial pressure in the Korean population. J Hum Genet 57(6):391-393. doi:10.1038/jhg.2012.31

International Consortium for Blood Pressure Genome-Wide Association Studies (2011) Genetic variants in novel pathways influence blood pressure and cardiovascular disease risk. Nature 478(7367):103-109. doi:10.1038/nature10405

International HapMap Consortium (2005) A haplotype map of the human genome. Nature 437(7063):1299-1320. doi:10.1038/nature04226

International HapMap Consortium (2007) A second generation human haplotype map of over 3.1 million SNPs. Nature 449(7164):851-861. doi:10.1038/nature06258

Ji W, Foo JN, O’Roak BJ, Zhao H, Larson MG, Simon DB, Newton-Cheh C, State MW, Levy D, Lifton RP (2008) Rare independent mutations in renal salt handling genes contribute to blood pressure variation. Nat Genet 40(5):592-599. doi:10.1038/ng.118

Johnson AD, Newton-Cheh C, Chasman DI, Ehret GB, Johnson T, Rose L, Rice K, Verwoert GC, Launer LJ, Gudnason V, Larson MG, Chakravarti A, Psaty BM, Caulfield M, van Duijn CM, Ridker PM, Munroe PB, Levy D, Cohorts for Heart and Aging Research in Genomic Epidemiology Consortium, Global BPgen Consortium, Women's Genome Health Study (2011a) Association of hypertension drug target genes with blood pressure and hypertension in 86,588 individuals. Hypertension 57(5):903-910. doi:10.1161/HYPERTENSIONAHA.110.158667

Johnson T, Gaunt TR, Newhouse SJ, Padmanabhan S, Tomaszewski M, Kumari M, Morris RW, Tzoulaki I, O'Brien ET, Poulter NR, Sever P, Shields DC, Thom S, Wannamethee SG, Whincup PH, Brown MJ, Connell JM, Dobson RJ, Howard PJ, Mein CA, Onipinla A, Shaw-Hawkins S, Zhang Y, Davey Smith G, Day IN, Lawlor DA, Goodall AH; Cardiogenics Consortium, Fowkes FG, Abecasis GR, Elliott P, Gateva V; Global BPgen Consortium, Braund PS, Burton PR, Nelson CP, Tobin MD, van der Harst P, Glorioso N, Neuvrith H, Salvi E, Staessen JA, Stucchi A, Devos N, Jeunemaitre X, Plouin PF, Tichet J, Juhanson P, Org E, Putku M, Sõber S, Veldre G, Viigimaa M, Levinsson A, Rosengren A, Thelle DS, Hastie CE, Hedner T, Lee WK, Melander O, Wahlstrand B, Hardy R, Wong A, Cooper JA, Palmen J, Chen L, Stewart AF, Wells GA, Westra HJ, Wolfs MG, Clarke R, Franzosi MG, Goel A, Hamsten A, Lathrop M, Peden JF, Seedorf U, Watkins H, Ouwehand WH, Sambrook J, Stephens J, Casas JP, Drenos F, Holmes MV, Kivimaki M, Shah S, Shah T, Talmud PJ, Whittaker J, Wallace C, Delles C, Laan M, Kuh D, Humphries SE, Nyberg F, Cusi D, Roberts R, Newton-Cheh C, Franke L, Stanton AV, Dominiczak AF, Farrall M, Hingorani AD, Samani NJ, Caulfield MJ, Munroe PB (2011) Blood pressure loci identified with a gene-centric array. Am J Hum Genet 89(6):688-700. doi:10.1016/j.ajhg.2011.10.013

Kamide K, Asayama K, Katsuya T, Ohkubo T, Hirose T, Inoue R, Metoki H, Kikuya M, Obara T, Hanada H, Thijs L, Kuznetsova T, Noguchi Y, Sugimoto K, Ohishi M, Morimoto S, Nakahashi T, Takiuchi S, Ishimitsu T, Tsuchihashi T, Soma M, Higaki J, Matsuura H, Shinagawa T, Sasaguri T, Miki T, Takeda K, Shimamoto K, Ueno M, Hosomi N, Kato J, Komai N, Kojima S, Sase K, Miyata T, Tomoike H, Kawano Y, Ogihara T, Rakugi H, Staessen JA, Imai Y, GEANE study group, HOMEDBP study group (2013) Genome-wide response to antihypertensive medication using home blood pressure measurements: a pilot study nested within the HOMED-BP study. Pharmacogenomics 14:1709-1721. doi:10.2217/ pgs.13.161

Kato N, Takeuchi F, Tabara Y, Kelly TN, Go MJ, Sim X, Tay WT, Chen CH, Zhang Y, Yamamoto K, Katsuya T, Yokota M, Kim YJ, Ong RT, Nabika T, Gu D, Chang LC, Kokubo Y, Huang W, Ohnaka K, Yamori Y, Nakashima E, Jaquish CE, Lee JY, Seielstad M, Isono M, Hixson JE, Chen YT, Miki T, Zhou X, Sugiyama T, Jeon JP, Liu JJ, Takayanagi R, Kim SS, Aung T, Sung YJ, Zhang X, Wong TY, Han BG, Kobayashi S, Ogihara T, Zhu D, Iwai N, Wu JY, Teo YY, Tai ES, Cho YS, He J (2011) Metaanalysis of genome-wide association studies identifies common variants associated with blood pressure variation in east Asians. Nat Genet 43(6):531-538. doi:10.1038/ng.834

Keating BJ, Tischfield S, Murray SS, Bhangale T, Price TS, Glessner JT, Galver L, Barrett JC, Grant SF, Farlow DN, Chandrupatla HR, Hansen M, Ajmal S, Papanicolaou GJ, Guo Y, Li M, Derohannessian S, de Bakker PI, Bailey SD, Montpetit A, Edmondson AC, Taylor K, Gai X, Wang SS, Fornage M, Shaikh T, Groop L, Boehnke M, Hall AS, Hattersley AT, Frackelton E, Patterson N, Chiang CW, Kim CE, Fabsitz RR, Ouwehand W, Price AL, Munroe P, Caulfield M, Drake T, Boerwinkle E, Reich D, Whitehead AS, Cappola TP, Samani NJ, Lusis AJ, Schadt E, Wilson JG, Koenig W, McCarthy MI, Kathiresan S, Gabriel SB, Hakonarson H, Anand SS, Reilly M, Engert JC, Nickerson DA, Rader DJ, Hirschhorn JN, Fitzgerald GA (2008) Concept, design and implementation of a cardiovascular gene-centric 50 k SNP array for large-scale genomic association studies. PLoS One 3(10):e3583. doi:10.1371/journal.pone.0003583

Kelly TN, Takeuchi F, Tabara Y, Edwards TL, Kim YJ, Chen P, Li H, Wu Y, Yang CF, Zhang Y, Gu D, Katsuya T, Ohkubo T, Gao YT, Go MJ, Teo YY, Lu L, Lee NR, Chang LC, Peng H, Zhao Q, Nakashima E, Kita Y, Shu XO, Kim NH, Tai ES, Wang Y, Adair LS, Chen CH, Zhang S, Li C, Nabika T, Umemura S, Cai Q, Cho YS, Wong TY, Zhu J, Wu JY, Gao X, Hixson JE, Cai H, Lee J, Cheng CY, Rao DC, Xiang YB, Cho MC, Han BG, Wang A, Tsai FJ, Mohlke K, Lin X, Ikram MK, Lee JY, Zheng W, Tetsuro M, Kato N, He J (2013) Genome-wide association study meta-analysis reveals transethnic replication of mean arterial and pulse pressure loci. Hypertension 62(5):853-859. doi:10.1161/HYPERTENSIONAHA.113.01148

Kraft P, Yen YC, Stram DO, Morrison J, Gauderman WJ (2007) Exploiting gene-environment interaction to detect genetic associations. Hum Hered 63(2):111-119. doi:10.1159/000099183

Kunes J, Zicha J (2009) The interaction of genetic and environmental factors in the etiology of hypertension. Physiol Res 58(Suppl 2):S33-S41

Levy D, Larson MG, Benjamin EJ, Newton-Cheh C, Wang TJ, Hwang SJ, Vasan RS, Mitchell GF (2007) Framingham Heart Study 100 K Project: genome-wide associations for blood pressure and arterial stiffness. BMC Med Genet 8(Supp 1):S3. doi:10.1186/1471-2350-8-S1-S3 
Levy D, Ehret GB, Rice K, Verwoert GC, Launer L, Dehghan A, Glazer NL, Morrison AC, Johnson AD, Aspelund T, Aulchenko Y, Lumley T, Köttgen A, Vasan RS, Rivadeneira F, Eiriksdottir G, Guo X, Arking DE, Mitchell GF, Mattace-Raso FU, Smith AV, Taylor K, Scharpf RB, Hwang SJ, Sijbrands EJ, Bis J, Harris TB, Ganesh SK, O'Donnell CJ, Hofman A, Rotter Jl, Coresh J, Benjamin EJ, Uitterlinden AG, Heiss G, Fox CS, Witteman JC, Boerwinkle E, Wang TJ, Gudnason V, Larson MG, Chakravarti A, Psaty BM, van Duijn CM (2009) Genome-wide association study of blood pressure and hypertension. Nat Genet 41(6):677-687. doi:10.1038/ng.384

Lewington S, Clarke R, Qizilbash N, Peto R, Collins R, Collaboration Prospective Studies (2002) Age-specific relevance of usual blood pressure to vascular mortality: a meta-analysis of individual data for one million adults in 61 prospective studies. Lancet 360(9349):1903-1913. doi:10.1016/S0140-6736(02)11911-8

LiY, Abecasis GR (2006) Mach 1.0: Rapid haplotype reconstruction and missing genotype inference. Am J Hum Genet $\mathrm{S} 79: 2290$

Lifton RP (1996) Molecular genetics of human blood pressure variation. Science 272(5262):676-680. doi:10.1126/ science. 272.5262 .676

Lin Y, Lai X, Chen B, Xu Y, Huang B, Chen Z, Zhu S, Yao J, Jiang Q, Huang H, Wen J, Chen G (2011) Genetic variations in CYP17A1, CACNB2 and PLEKHA7 are associated with blood pressure and/or hypertension in She ethnic minority of China. Atherosclerosis 219(2):709-714. doi:10.1016/j.atherosclerosis.2011.09.006

Lu X, Wang L, Lin X, Huang J, Charles GuC, He M, Shen H, He J, Zhu J, Li H, Hixson JE, Wu T, Dai J, Lu L, Shen C, Chen S, He L, Mo Z, Hao Y, Mo X, Yang X, Li J, Cao J, Chen J, Fan Z, Li Y, Zhao L, Li H, Lu F, Yao C, Yu L, Xu L, Mu J, Wu X, Deng Y, Hu D, Zhang W, Ji X, Guo D, Guo Z, Zhou Z, Yang Z, Wang R, Yang J, Zhou X, Yan W, Sun N, Gao P, Gu D (2014) Genomewide association study in Chinese identifies novel loci for blood pressure and hypertension. Hum Mol Genet 24(3):865-874. doi: 10.1093/hmg/ddu478

Manolio TA, Collins FS, Cox NJ, Goldstein DB, Hindorff LA, Hunter DJ, McCarthy MI, Ramos EM, Cardon LR, Chakravarti A, Cho JH, Guttmacher AE, Kong A, Kruglyak L, Mardis E, Rotimi CN, Slatkin M, Valle D, Whittemore AS, Boehnke M, Clark AG, Eichler EE, Gibson G, Haines JL, Mackay TF, McCarroll SA, Visscher PM (2009) Finding the missing heritability of complex diseases. Nature 461(7265):747-753. doi:10.1038/nature08494

Marchini J, Howie B, Myers S, McVean G, Donnelly P (2007) A new multipoint method for genomewide association studies by imputation of genotypes. Nat Genet 39(7):906-913. doi:10.1038/ng2088

Metzker ML (2010) Sequencing technologies—-the next generation. Nat Rev Genet 11(1):31-46. doi:10.1038/nrg2626

Miall WE, Oldham PD (1963) The hereditary factor in arterial blood-pressure. Br Med J 1(5323):75-80. doi:10.1136/ bmj.1.5323.75

Morrison AC, Bis JC, Hwang SJ, Ehret GB, Lumley T, Rice K, Muzny D, Gibbs RA, Boerwinkle E, Psaty BM, Chakravarti A, Levy D (2014) Sequence analysis of six blood pressure candidate regions in 4178 individuals: the Cohorts for Heart and Aging Research in Genomic Epidemiology (CHARGE) targeted sequencing study. PLoS One 9(10):e109155. doi:10.1371/journal.pone.0109155

Neal B, MacMahon S, Chapman N, Blood Pressure Lowering Treatment Trialists' Collaboration (2000) Effects of ACE inhibitors, calcium antagonists, and other blood-pressure-lowering drugs: results of prospectively designed overviews of randomised trials. Lancet 356(9246):1955-1964. doi:10.1016/S0140-6736(00)03307-9

Newton-Cheh C, Johnson T, Gateva V, Tobin MD, Bochud M, Coin L, Najjar SS, Zhao JH, Heath SC, Eyheramendy S, Papadakis K, Voight BF, Scott LJ, Zhang F, Farrall M, Tanaka T, Wallace C, Chambers JC, Khaw KT, Nilsson P, van der Harst P, Polidoro S, Grobbee DE, Onland-Moret NC, Bots ML, Wain LV, Elliott KS, Teumer A, Luan J, Lucas G, Kuusisto J, Burton PR, Hadley D, McArdle WL; Wellcome Trust Case Control Consortium, Brown M, Dominiczak A, Newhouse SJ, Samani NJ, Webster J, Zeggini E, Beckmann JS, Bergmann S, Lim N, Song K, Vollenweider P, Waeber G, Waterworth DM, Yuan X, Groop L, Orho-Melander M, Allione A, Di Gregorio A, Guarrera S, Panico S, Ricceri F, Romanazzi V, Sacerdote C, Vineis P, Barroso I, Sandhu MS, Luben RN, Crawford GJ, Jousilahti P, Perola M, Boehnke M, Bonnycastle LL, Collins FS, Jackson AU, Mohlke KL, Stringham HM, Valle TT, Willer CJ, Bergman RN, Morken MA, Döring A, Gieger C, Illig T, Meitinger T, Org E, Pfeufer A, Wichmann HE, Kathiresan S, Marrugat J, O'Donnell CJ, Schwartz SM, Siscovick DS, Subirana I, Freimer NB, Hartikainen AL, McCarthy MI, O'Reilly PF, Peltonen L, Pouta A, de Jong PE, Snieder H, van Gilst WH, Clarke R, Goel A, Hamsten A, Peden JF, Seedorf U, Syvänen AC, Tognoni G, Lakatta EG, Sanna S, Scheet P, Schlessinger D, Scuteri A, Dörr M, Ernst F, Felix SB, Homuth G, Lorbeer R, Reffelmann T, Rettig R, Völker U, Galan P, Gut IG, Hercberg S, Lathrop GM, Zelenika D, Deloukas P, Soranzo N, Williams FM, Zhai G, Salomaa V, Laakso M, Elosua R, Forouhi NG, Völzke H, Uiterwaal CS, van der Schouw YT, Numans ME, Matullo G, Navis G, Berglund G, Bingham SA, Kooner JS, Connell JM, Bandinelli S, Ferrucci L, Watkins H, Spector TD, Tuomilehto J, Altshuler D, Strachan DP, Laan M, Meneton P, Wareham NJ, Uda M, Jarvelin MR, Mooser V, Melander O, Loos RJ, Elliott P, Abecasis GR, Caulfield M, Munroe PB (2009) Genome-wide association study identifies eight loci associated with blood pressure. Nat Genet 41(6):666-676. doi:10.1038/ng.361

Nguyen KD, Pihur V, Ganesh SK, Rakha A, Cooper RS, Hunt SC, Freedman BI, Coresh J, Kao WH, Morrison AC, Boerwinkle E, Ehret GB, Chakravarti A (2013) Effects of rare and common blood pressure gene variants on essential hypertension: results from the Family Blood Pressure Program, CLUE, and Atherosclerosis Risk in Communities studies. Circ Res 112(2):318-326. doi:10.1161/CIRCRESAHA.112.276725

Org E, Eyheramendy S, Juhanson P, Gieger C, Lichtner P, Klopp N, Veldre G, Döring A, Viigimaa M, Söber S, Tomberg K, Eckstein G; KORA, Kelgo P, Rebane T, Shaw-Hawkins S, Howard P, Onipinla A, Dobson RJ, Newhouse SJ, Brown M, Dominiczak A, Connell J, Samani N, Farrall M; BRIGHT, Caulfield MJ, Munroe PB, Illig T, Wichmann HE, Meitinger T, Laan M (2009) Genome-wide scan identifies CDH13 as a novel susceptibility locus contributing to blood pressure determination in two European populations. Hum Mol Genet 18(12):2288-2296. doi:10.1093/hmg/ddp135

Padmanabhan S, Melander O, Johnson T, Di Blasio AM, Lee WK, Gentilini D, Hastie CE, Menni C, Monti MC, Delles C, Laing S, Corso B, Navis G, Kwakernaak AJ, van der Harst P, Bochud M, Maillard M, Burnier M, Hedner T, Kjeldsen S, Wahlstrand B, Sjögren M, Fava C, Montagnana M, Danese E, Torffvit O, Hedblad B, Snieder H, Connell JM, Brown M, Samani NJ, Farrall M, Cesana G, Mancia G, Signorini S, Grassi G, Eyheramendy S, Wichmann HE, Laan M, Strachan DP, Sever P, Shields DC, Stanton A, Vollenweider P, Teumer A, Völzke H, Rettig R, Newton-Cheh C, Arora P, Zhang F, Soranzo N, Spector TD, Lucas G, Kathiresan S, Siscovick DS, Luan J, Loos RJ, Wareham NJ, Penninx BW, Nolte IM, McBride M, Miller WH, Nicklin SA, Baker AH, Graham D, McDonald RA, Pell JP, Sattar N, Welsh P; Global BPgen 
Consortium, Munroe P, Caulfield MJ, Zanchetti A, Dominiczak AF (2010) Genome-wide association study of blood pressure extremes identifies variant near UMOD associated with hypertension. PLoS Genet 6(10):e1001177. doi:10.1371/journal.pgen.1001177

Padmanabhan S, Caulfield M, Dominiczak AF (2015) Genetic and molecular aspects of hypertension. Circ Res 116(6):937959. doi:10.1161/CIRCRESAHA.116.303647

Parra EJ, Marcini A, Akey J, Martinson J, Batzer MA, Cooper R, Forrester T, Allison DB, Deka R, Ferrell RE, Shriver MD (1998) Estimating African American admixture proportions by use of population-specific alleles. Am J Hum Genet 63(6):1839-1851. doi:10.1086/302148

Pe'er I, Yelensky R, Altshuler D, Daly MJ (2008) Estimation of the multiple testing burden for genomewide association studies of nearly all common variants. Genet Epidemiol 32(4):381-385. doi:10.1002/gepi.20303

Pickering G (1965) Hyperpiesis: high blood-pressure without evident cause: essential hypertension. Br Med J 2(5468):959-968

Qi Y, Zhao H, Wang Y, Wang Y, Lu C, Xiao Y, Cao J, Jia N, Wang B, Niu W (2014) Replication of the top 10 most significant polymorphisms from a large blood pressure genome-wide association study of northeastern Han Chinese East Asians. Hypertens Res 37(2):134-138. doi:10.1038/hr.2013.132

Rosamond W, Flegal K, Friday G, Furie K, Go A, Greenlund K, Haase N, Ho M, Howard V, Kissela B, Kittner S, LloydJones D, McDermott M, Meigs J, Moy C, Nichol G, O'Donnell CJ, Roger V, Rumsfeld J, Sorlie P, Steinberger J, Thom T, Wasserthiel-Smoller S, Hong Y, American Heart Association Statistics Committee and Stroke Statistics Subcommittee (2007) Heart disease and stroke statistics—2007 update: a report from the American Heart Association Statistics Committee and Stroke Statistics Subcommittee. Circulation 115(5):e69-e171. doi:10.1161/ CIRCULATIONAHA.106.179918

Salvi E, Kutalik Z, Glorioso N, Benaglio P, Frau F, Kuznetsova T, Arima H, Hoggart C, Tichet J, Nikitin YP, Conti C, Seidlerova J, Tikhonoff V, Stolarz-Skrzypek K, Johnson T, Devos N, Zagato L, Guarrera S, Zaninello R, Calabria A, Stancanelli B, Troffa C, Thijs L, Rizzi F, Simonova G, Lupoli S, Argiolas G, Braga D, D’Alessio MC, Ortu MF, Ricceri F, Mercurio M, Descombes P, Marconi M, Chalmers J, Harrap S, Filipovsky J, Bochud M, lacoviello L, Ellis J, Stanton AV, Laan M, Padmanabhan S, Dominiczak AF, Samani NJ, Melander O, Jeunemaitre X, Manunta P, Shabo A, Vineis P, Cappuccio FP, Caulfield MJ, Matullo G, Rivolta C, Munroe PB, Barlassina C, Staessen JA, Beckmann JS, Cusi D (2012) Genomewide association study using a high-density single nucleotide polymorphism array and case-control design identifies a novel essential hypertension susceptibility locus in the promoter region of endothelial NO synthase. Hypertension 59(2):248-255. doi:10.1161/HYPERTENSIONAHA.111.181990

Servin B, Stephens M (2007) Imputation-based analysis of association studies: candidate regions and quantitative traits. PLoS Genet 3(7):e114. doi:10.1371/journal.pgen.0030114

Shi G, Rao DC (2011) Optimum designs for next-generation sequencing to discover rare variants for common complex disease. Genet Epidemiol 35(6):572-579. doi:10.1002/gepi.20597

Shi G, Boerwinkle E, Morrison AC, Gu CC, Chakravarti A, Rao DC (2011) Mining gold dust under the genome wide significance level: a two-stage approach to analysis of GWAS. Genet Epidemiol 35(2):111-118. doi:10.1002/gepi.20556

Simino J, Shi G, Bis JC, Chasman DI, Ehret GB, Gu X, Guo X, Hwang SJ, Sijbrands E, Smith AV, Verwoert GC, Bragg-Gresham JL, Cadby G, Chen P, Cheng CY, Corre T, de Boer RA, Goel A, Johnson T, Khor CC; LifeLines Cohort Study, LluísGanella C, Luan J, Lyytikäinen LP, Nolte IM, Sim X, Sõber S, van der Most PJ, Verweij N, Zhao JH, Amin N, Boerwinkle E, Bouchard C, Dehghan A, Eiriksdottir G, Elosua R, Franco OH, Gieger C, Harris TB, Hercberg S, Hofman A, James AL, Johnson AD, Kähönen M, Khaw KT, Kutalik Z, Larson MG, Launer LJ, Li G, Liu J, Liu K, Morrison AC, Navis G, Ong RT, Papanicolau GJ, Penninx BW, Psaty BM, Raffel LJ, Raitakari OT, Rice K, Rivadeneira F, Rose LM, Sanna S, Scott RA, Siscovick DS, Stolk RP, Uitterlinden AG, Vaidya D, van der Klauw MM, Vasan RS, Vithana EN, Völker U, Völzke H, Watkins H, Young TL, Aung T, Bochud M, Farrall M, Hartman CA, Laan M, Lakatta EG, Lehtimäki T, Loos RJ, Lucas G, Meneton P, Palmer LJ, Rettig R, Snieder H, Tai ES, Teo YY, van der Harst P, Wareham NJ, Wijmenga C, Wong TY, Fornage M, Gudnason V, Levy D, Palmas W, Ridker PM, Rotter JI, van Duijn CM, Witteman JC, Chakravarti A, Rao DC (2014) Geneage interactions in blood pressure regulation: a large-scale investigation with the CHARGE, Global BPgen, and ICBP Consortia. Am J Hum Genet 95(1):24-38. doi:10.1016/j.ajhg.2014.05.010

Simino J, Rao DC, Freedman BI (2012) Novel findings and future directions on the genetics of hypertension. Curr Opin Nephrol Hypertens 21(5):500-507. doi:10.1097/MNH.0b013e328354e78f

Simino J, Sung YJ, Kume R, Schwander K, Rao DC (2013) Gene-alcohol interactions identify several novel blood pressure loci including a promising locus near SLC16A9. Front Genet 4:277. doi:10.3389/fgene.2013.00277

Sung YJ, de Las Fuentes L, Schwander KL, Simino J, Rao DC (2014) Gene-Smoking interactions identify several novel blood pressure loci in the framingham heart study. Am J Hypertens 28(3):343-354. doi:10.1093/ajh/hpu149

Tabara Y, Kohara K, Kita Y, Hirawa N, Katsuya T, Ohkubo T, Hiura Y, Tajima A, Morisaki T, Miyata T, Nakayama T, Takashima N, Nakura J, Kawamoto R, Takahashi N, Hata A, Soma M, Imai Y, Kokubo Y, Okamura T, Tomoike H, Iwai N, Ogihara T, Inoue I, Tokunaga K, Johnson T, Caulfield M, Munroe P; Global Blood Pressure Genetics Consortium, Umemura S, Ueshima H, Miki T (2010) Common variants in the ATP2B1 gene are associated with susceptibility to hypertension: the Japanese Millennium Genome Project. Hypertension 56(5):973-980. doi:10.1161/ HYPERTENSIONAHA.110.153429

Takeuchi F, Isono M, Katsuya T, Yamamoto K, Yokota M, Sugiyama T, Nabika T, Fujioka A, Ohnaka K, Asano H, Yamori Y, Yamaguchi S, Kobayashi S, Takayanagi R, Ogihara T, Kato N (2010) Blood pressure and hypertension are associated with 7 loci in the Japanese population. Circulation 121(21):2302-2309. doi:10.1161/CIRCULATIONAHA.109.904664

Thomas DC (2004) Statistical Methods in Genetic Epidemiology. Oxford University Press, New York

Tomaszewski M, Debiec R, Braund PS, Nelson CP, Hardwick R, Christofidou P, Denniff M, Codd V, Rafelt S, van der Harst P, Waterworth D, Song K, Vollenweider P, Waeber G, Zukowska-Szczechowska E, Burton PR, Mooser V, Charchar FJ, Thompson JR, Tobin MD, Samani NJ (2010) Genetic architecture of ambulatory blood pressure in the general population: insights from cardiovascular gene-centric array. Hypertension 56(6):1069-1076. doi:10.1161/ HYPERTENSIONAHA. 110.155721

Tragante V, Barnes MR, Ganesh SK, Lanktree MB, Guo W, Franceschini N, Smith EN, Johnson T, Holmes MV, Padmanabhan S, Karczewski KJ, Almoguera B, Barnard J, Baumert J, Chang YP, Elbers CC, Farrall M, Fischer ME, Gaunt TR, Gho JM, 
Gieger C, Goel A, Gong Y, Isaacs A, Kleber ME, Mateo Leach I, McDonough CW, Meijs MF, Melander O, Nelson CP, Nolte IM, Pankratz N, Price TS, Shaffer J, Shah S, Tomaszewski M, van der Most PJ, Van Iperen EP, Vonk JM, Witkowska K, Wong CO, Zhang L, Beitelshees AL, Berenson GS, Bhatt DL, Brown M, Burt A, Cooper-DeHoff RM, Connell JM, Cruickshanks KJ, Curtis SP, Davey-Smith G, Delles C, Gansevoort RT, Guo X, Haiqing S, Hastie CE, Hofker MH, Hovingh GK, Kim DS, Kirkland SA, Klein BE, Klein R, Li YR, Maiwald S, Newton-Cheh C, O'Brien ET, Onland-Moret NC, Palmas W, Parsa A, Penninx BW, Pettinger M, Vasan RS, Ranchalis JE, M Ridker P, Rose LM, Sever P, Shimbo D, Steele L, Stolk RP, Thorand B, Trip MD, van Duijn CM, Verschuren WM, Wijmenga C, Wyatt S, Young JH, Zwinderman AH, Bezzina CR, Boerwinkle E, Casas JP, Caulfield MJ, Chakravarti A, Chasman DI, Davidson KW, Doevendans PA, Dominiczak AF, FitzGerald GA, Gums JG, Fornage M, Hakonarson H, Halder I, Hillege HL, Illig T, Jarvik GP, Johnson JA, Kastelein JJ, Koenig W, Kumari M, März W, Murray SS, O'Connell JR, Oldehinkel AJ, Pankow JS, Rader DJ, Redline S, Reilly MP, Schadt EE, Kottke-Marchant K, Snieder H, Snyder M, Stanton AV, Tobin MD, Uitterlinden AG, van der Harst P, van der Schouw YT, Samani NJ, Watkins H, Johnson AD, Reiner AP, Zhu X, de Bakker PI, Levy D, Asselbergs FW, Munroe PB, Keating BJ (2014) Gene-centric meta-analysis in 87,736 individuals of European ancestry identifies multiple bloodpressure-related loci. Am J Hum Genet 94(3):349-360. doi:10.1016/j.ajhg.2013.12.016

Turner ST, Bailey KR, Fridley BL, Chapman AB, Schwartz GL, Chai HS, Sicotte H, Kocher JP, Rodin AS, Boerwinkle E (2008) Genomic association analysis suggests chromosome 12 locus influencing antihypertensive response to thiazide diuretic. Hypertension 52(2):359-365. doi:10.1161/HYPERTENSIONAHA.107.104273

Turner ST, Boerwinkle E, O'Connell JR, Bailey KR, Gong Y, Chapman AB, McDonough CW, Beitelshees AL, Schwartz GL, Gums JG, Padmanabhan S, Hiltunen TP, Citterio L, Donner KM, Hedner T, Lanzani C, Melander O, Saarela J, Ripatti S, Wahlstrand B, Manunta P, Kontula K, Dominiczak AF, Cooper-DeHoff RM, Johnson JA (2013) Genomic association analysis of common variants influencing antihypertensive response to hydrochlorothiazide. Hypertension 62(2):391-397. doi:10.1161/HYPERTENSIONAHA.111.00436

van Leeuwen EM, Smouter FA, Kam-Thong T, Karbalai N, Smith AV, Harris TB, Launer L, Sitlani CM, Li G, Brody JA, Bis JC, White CC, Jaiswal A, Oostra BA, Hofman A, Rivadeneira F, Uitterlinden AG, Boerwinkle E, Ballantyne CM, Gudnason V, Psaty BM, Cupples LA, Järvelin MR, Ripatti S, Isaacs A, Müller-Myhsok B, Karssen LC, van Duijn CM (2014) The challenges of genome-wide interaction studies: lessons to learn from the analysis of HDL blood levels. PLoS One 9(10):e109290. doi:10.1371/journal.pone.0109290

Wain LV, Verwoert GC, O'Reilly PF, Shi G, Johnson T, Johnson AD, Bochud M, Rice KM, Henneman P, Smith AV, Ehret GB, Amin N, Larson MG, Mooser V, Hadley D, Dörr M, Bis JC, Aspelund T, Esko T, Janssens AC, Zhao JH, Heath S, Laan M, Fu J, Pistis G, Luan J, Arora P, Lucas G, Pirastu N, Pichler I, Jackson AU, Webster RJ, Zhang F, Peden JF, Schmidt H, Tanaka T, Campbell H, IgI W, Milaneschi Y, Hottenga JJ, Vitart V, Chasman DI, Trompet S, Bragg-Gresham JL, Alizadeh BZ, Chambers JC, Guo X, Lehtimäki T, Kühnel B, Lopez LM, Polašek O, Boban M, Nelson CP, Morrison AC, Pihur V, Ganesh SK, Hofman A, Kundu S, Mattace-Raso FU, Rivadeneira F, Sijbrands EJ, Uitterlinden AG, Hwang SJ, Vasan RS, Wang TJ, Bergmann S, Vollenweider P, Waeber G, Laitinen J, Pouta A, Zitting P, McArdle WL, Kroemer HK, Völker U, Völzke H, Glazer NL, Taylor KD, Harris TB, Alavere H, Haller T, Keis A, Tammesoo ML, Aulchenko Y, Barroso I, Khaw KT, Galan P, Hercberg S, Lathrop M, Eyheramendy S, Org E, Söber S, Lu X, Nolte IM, Penninx BW, Corre T, Masciullo C, Sala C, Groop L, Voight BF, Melander O, O'Donnell CJ, Salomaa V, d'Adamo AP, Fabretto A, Faletra F, Ulivi S, Del Greco F, Facheris M, Collins FS, Bergman RN, Beilby JP, Hung J, Musk AW, Mangino M, Shin SY, Soranzo N, Watkins H, Goel A, Hamsten A, Gider P, Loitfelder M, Zeginigg M, Hernandez D, Najjar SS, Navarro P, Wild SH, Corsi AM, Singleton A, de Geus EJ, Willemsen G, Parker AN, Rose LM, Buckley B, Stott D, Orru M, Uda M; LifeLines Cohort Study, van der Klauw MM, Zhang W, Li X, Scott J, Chen YD, Burke GL, Kähönen M, Viikari J, Döring A, Meitinger T, Davies G, Starr JM, Emilsson V, Plump A, Lindeman JH, Hoen PA, König IR; EchoGen consortium, Felix JF, Clarke R, Hopewell JC, Ongen H, Breteler M, Debette S, Destefano AL, Fornage M; AortaGen Consortium, Mitchell GF; CHARGE Consortium Heart Failure Working Group, Smith NL; KidneyGen consortium, Holm H, Stefansson K, Thorleifsson G, Thorsteinsdottir U; CKDGen consortium; Cardiogenics consortium; CardioGram, Samani NJ, Preuss M, Rudan I, Hayward C, Deary IJ, Wichmann HE, Raitakari OT, Palmas W, Kooner JS, Stolk RP, Jukema JW, Wright AF, Boomsma DI, Bandinelli S, Gyllensten UB, Wilson JF, Ferrucci L, Schmidt R, Farrall M, Spector TD, Palmer L, Tuomilehto J, Pfeufer A, Gasparini P, Siscovick D, Altshuler D, Loos RJ, Toniolo D, Snieder H, Gieger C, Meneton P, Wareham NJ, Oostra BA, Metspalu A, Launer L, Rettig R, Strachan DP, Beckmann JS, Witteman JC, Erdmann J, van Dijk KW, Boerwinkle E, Boehnke M, Ridker PM, Jarvelin MR, Chakravarti A, Abecasis GR, Gudnason V, Newton-Cheh C, Levy D, Munroe PB, Psaty BM, Caulfield MJ, Rao DC, Tobin MD, Elliott P, van Duijn CM (2011) Genome-wide association study identifies six new loci influencing pulse pressure and mean arterial pressure. Nat Genet 43(10):1005-1011. doi:10.1038/ng.922

Wang Y, O'Connell JR, MCArdle PF, Wade JB, Dorff SE, Shah SJ, Shi X, Pan L, Rampersaud E, Shen H, Kim JD, Subramanya AR, Steinle NI, Parsa A, Ober CC, Welling PA, Chakravarti A, Weder AB, Cooper RS, Mitchell BD, Shuldiner AR, Chang YP (2009) Whole-genome association study identifies STK39 as a hypertension susceptibility gene. Proc Natl Acad Sci USA 106(1):226-231. doi:10.1073/pnas.0808358106

Wang X, Prins BP, Sõber S, Laan M, Snieder H (2011) Beyond genome-wide association studies: new strategies for identifying genetic determinants of hypertension. Curr Hypertens Rep 13(6):442-451. doi:10.1007/s1 1906-011-0230-y

Wang X, Falkner B, Zhu H, Shi H, Su S, Xu X, Sharma AK, Dong Y, Treiber F, Gutin B, Harshfield G, Snieder H (2013a) A genome-wide methylation study on essential hypertension in young African American males. PLoS One 8(1):e53938. doi:10.1371/journal.pone.0053938

Wang Y, Zhang Y, Li Y, Zhou X, Wang X, Gao P, Jin L, Zhang X, Zhu D (2013b) Common variants in the ATP2B1 gene are associated with hypertension and arterial stiffness in Chinese population. Mol Biol Rep 40(2):1867-1873. doi:10.1007/s11033-012-2242-3

Wellcome Trust Case Control Consortium (2007) Genome-wide association study of 14,000 cases of seven common diseases and 3000 shared controls. Nature 447(7145):661-678. doi:10.1038/nature05911

Whitworth JA, World Health Organization International Society of Hypertension Writing Group (2003) 2003 World Health Organization (WHO)/International Society of Hypertension (ISH) statement on management of hypertension. J Hypertens 21(11):1983-1992

Wood AR, Esko T, Yang J, Vedantam S, Pers TH, Gustafsson S, Chu AY, Estrada K, Luan J, Kutalik Z, Amin N, Buchkovich ML, Croteau-Chonka DC, Day FR, Duan Y, Fall T, Fehrmann R, Ferreira T, Jackson AU, Karjalainen J, Lo KS, Locke AE, Mägi R, 
Mihailov E, Porcu E, Randall JC, Scherag A, Vinkhuyzen AA, Westra HJ, Winkler TW, Workalemahu T, Zhao JH, Absher D, Albrecht E, Anderson D, Baron J, Beekman M, Demirkan A, Ehret GB, Feenstra B, Feitosa MF, Fischer K, Fraser RM, Goel A, Gong J, Justice AE, Kanoni S, Kleber ME, Kristiansson K, Lim U, Lotay V, Lui JC, Mangino M, Mateo Leach I, Medina-Gomez C, Nalls MA, Nyholt DR, Palmer CD, Pasko D, Pechlivanis S, Prokopenko I, Ried JS, Ripke S, Shungin D, Stancáková A, Strawbridge RJ, Sung YJ, Tanaka T, Teumer A, Trompet S, van der Laan SW, van Setten J, Van VlietOstaptchouk JV, Wang Z, Yengo L, Zhang W, Afzal U, Arnlöv J, Arscott GM, Bandinelli S, Barrett A, Bellis C, Bennett AJ, Berne C, Blüher M, Bolton JL, Böttcher Y, Boyd HA, Bruinenberg M, Buckley BM, Buyske S, Caspersen IH, Chines PS, Clarke R, Claudi-Boehm S, Cooper M, Daw EW, De Jong PA, Deelen J, Delgado G, Denny JC, Dhonukshe-Rutten R, Dimitriou M, Doney AS, Dörr M, Eklund N, Eury E, Folkersen L, Garcia ME, Geller F, Giedraitis V, Go AS, Grallert H, Grammer TB, Gräßler J, Grönberg H, de Groot LC, Groves CJ, Haessler J, Hall P, Haller T, Hallmans G, Hannemann A, Hartman CA, Hassinen M, Hayward C, Heard-Costa NL, Helmer Q, Hemani G, Henders AK, Hillege HL, Hlatky MA, Hoffmann W, Hoffmann P, Holmen O, Houwing-Duistermaat JJ, Illig T, Isaacs A, James AL, Jeff J, Johansen B, Johansson A, Jolley J, Juliusdottir T, Junttila J, Kho AN, Kinnunen L, Klopp N, Kocher T, Kratzer W, Lichtner P, Lind L, Lindström J, Lobbens S, Lorentzon M, LuY, Lyssenko V, Magnusson PK, Mahajan A, Maillard M, McArdle WL, McKenzie CA, McLachlan S, McLaren PJ, Menni C, Merger S, Milani L, Moayyeri A, Monda KL, Morken MA, Müller G, Müller-Nurasyid M, Musk AW, Narisu N, Nauck M, Nolte IM, Nöthen MM, Oozageer L, Pilz S, Rayner NW, Renstrom F, Robertson NR, Rose LM, Roussel R, Sanna S, Scharnagl H, Scholtens S, Schumacher FR, Schunkert H, Scott RA, Sehmi J, Seufferlein T, Shi J, Silventoinen K, Smit JH, Smith AV, Smolonska J, Stanton AV, Stirrups K, Stott DJ, Stringham HM, Sundström J, Swertz MA, Syvänen AC, Tayo BO, Thorleifsson G, Tyrer JP, van Dijk S, van Schoor NM, van der Velde N, van Heemst D, van Oort FV, Vermeulen SH, Verweij N, Vonk JM, Waite LL, Waldenberger M, Wennauer R, Wilkens LR, Willenborg C, Wilsgaard T, Wojczynski MK, Wong A, Wright AF, Zhang Q, Arveiler D, Bakker SJ, Beilby J, Bergman RN, Bergmann S, Biffar R, Blangero J, Boomsma DI, Bornstein SR, Bovet P, Brambilla P, Brown MJ, Campbell H, Caulfield MJ, Chakravarti A, Collins R, Collins FS, Crawford DC, Cupples LA, Danesh J, de Faire U, den Ruijter HM, Erbel R, Erdmann J, Eriksson JG, Farrall M, Ferrannini E, Ferrières J, Ford I, Forouhi NG, Forrester T, Gansevoort RT, Gejman PV, Gieger C, Golay A, Gottesman O, Gudnason V, Gyllensten U, Haas DW, Hall AS, Harris TB, Hattersley AT, Heath AC, Hengstenberg C, Hicks AA, Hindorff LA, Hingorani AD, Hofman A, Hovingh GK, Humphries SE, Hunt SC, Hypponen E, Jacobs KB, Jarvelin MR, Jousilahti P, Jula AM, Kaprio J, Kastelein JJ, Kayser M, Kee F, Keinanen-Kiukaanniemi SM, Kiemeney LA, Kooner JS, Kooperberg C, Koskinen S, Kovacs P, Kraja AT, Kumari M, Kuusisto J, Lakka TA, Langenberg C, Le Marchand L, Lehtimäki T, Lupoli S, Madden PA, Männistö S, Manunta P, Marette A, Matise TC, McKnight B, Meitinger T, Moll FL, Montgomery GW, Morris AD, Morris AP, Murray JC, Nelis M, OhIsson C, Oldehinkel AJ, Ong KK, Ouwehand WH, Pasterkamp G, Peters A, Pramstaller PP, Price JF, Qi L, Raitakari OT, Rankinen T, Rao DC, Rice TK, Ritchie M, Rudan I, Salomaa V, Samani NJ, Saramies J, Sarzynski MA, Schwarz PE, Sebert S, Sever P, Shuldiner AR, Sinisalo J, Steinthorsdottir V, Stolk RP, Tardif JC, Tönjes A, Tremblay A, Tremoli E, Virtamo J, Vohl MC; Electronic Medical Records and Genomics (eMERGE) Consortium; MIGen Consortium; PAGE Consortium; LifeLines Cohort Study, Amouyel P, Asselbergs FW, Assimes TL, Bochud M, Boehm BO, Boerwinkle E, Bottinger EP, Bouchard C, Cauchi S, Chambers JC, Chanock SJ, Cooper RS, de Bakker PI, Dedoussis G, Ferrucci L, Franks PW, Froguel P, Groop LC, Haiman CA, Hamsten A, Hayes MG, Hui J, Hunter DJ, Hveem K, Jukema JW, Kaplan RC, Kivimaki M, Kuh D, Laakso M, Liu Y, Martin NG, März W, Melbye M, Moebus S, Munroe PB, Njølstad I, Oostra BA, Palmer CN, Pedersen NL, Perola M, Pérusse L, Peters U, Powell JE, Power C, Quertermous T, Rauramaa R, Reinmaa E, Ridker PM, Rivadeneira F, Rotter JI, Saaristo TE, Saleheen D, Schlessinger D, Slagboom PE, Snieder H, Spector TD, Strauch K, Stumvoll M, Tuomilehto J, Uusitupa M, van der Harst P, Völzke H, Walker M, Wareham NJ, Watkins H, Wichmann HE, Wilson JF, Zanen P, Deloukas P, Heid IM, Lindgren CM, Mohlke KL, Speliotes EK, Thorsteinsdottir U, Barroso I, Fox CS, North KE, Strachan DP, Beckmann JS, Berndt SI, Boehnke M, Borecki IB, McCarthy MI, Metspalu A, Stefansson K, Uitterlinden AG, van Duijn CM, Franke L, Willer CJ, Price AL, Lettre G, Loos RJ, Weedon MN, Ingelsson E, O'Connell JR, Abecasis GR, Chasman DI, Goddard ME, Visscher PM, Hirschhorn JN, Frayling TM (2014) Defining the role of common variation in the genomic and biological architecture of adult human height. Nat Genet 46(11):1173-1186. doi:10.1038/ng.3097

World Health Organization (2002) The World Health Report 2002: Risks to Health. World Health Organization, Geneva Xu X, Shi G, Nehorai A (2013) Meta-regression of gene-environment interaction in genome-wide association studies. IEEE Trans Nanobiosci 12(4):354-362. doi:10.1109/TNB.2013.2294331

Yadav S, Cotlarciuc I, Munroe PB, Khan MS, Nalls MA, Bevan S, Cheng YC, Chen WM, Malik R, McCarthy NS, Holliday EG, Speed D, Hasan N, Pucek M, Rinne PE, Sever P, Stanton A, Shields DC, Maguire JM, McEvoy M, Scott RJ, Ferrucci L, Macleod MJ, Attia J, Markus HS, Sale MM, Worrall BB, Mitchell BD, Dichgans M, Sudlow C, Meschia JF, Rothwell PM, Caulfield M, Sharma P, International Stroke Genetics Consortium (2013) Genome-wide analysis of blood pressure variability and ischemic stroke. Stroke 44(10):2703-2709. doi:10.1161/STROKEAHA.113.002186

Yu K, Chatterjee N, Wheeler W, Li Q, Wang S, Rothman N, Wacholder S (2007) Flexible design for following up positive findings. Am J Hum Genet 81 (3):540-551. doi:10.1086/520678

Zhu X, Tang H, Risch N (2008) Admixture mapping and the role of population structure for localizing disease genes. Adv Genet 60:547-569. doi:10.1016/S0065-2660(07)00419-1

Zhu X, Young JH, Fox E, Keating BJ, Franceschini N, Kang S, Tayo B, Adeyemo A, Sun YV, Li Y, Morrison A, Newton-Cheh C, Liu K, Ganesh SK, Kutlar A, Vasan RS, Dreisbach A, Wyatt S, Polak J, Palmas W, Musani S, Taylor H, Fabsitz R, Townsend RR, Dries D, Glessner J, Chiang CW, Mosley T, Kardia S, Curb D, Hirschhorn JN, Rotimi C, Reiner A, Eaton C, Rotter Jl, Cooper RS, Redline S, Chakravarti A, Levy D (2011) Combined admixture mapping and association analysis identifies a novel blood pressure genetic locus on 5p13: contributions from the CARe consortium. Hum Mol Genet 20(11):2285-2295. doi:10.1093/hmg/ddr113 